\title{
Energy History \\ Chronology from World \\ War II to the Present
}

August 1982

\section{DO NOT MICROFILM \\ COVER}

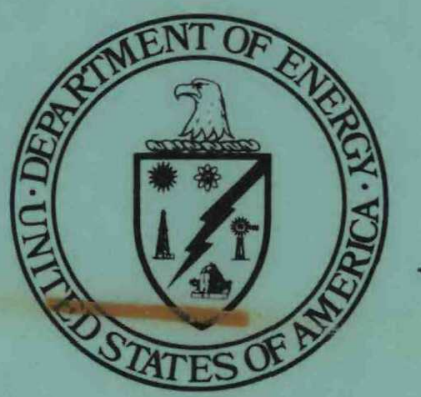

U.S. Department of Energy

Assistant Secretary, Management and Administration

Office of The Executive Secretary 


\section{DISCLAIMER}

This report was prepared as an account of work sponsored by an agency of the United States Government. Neither the United States Government nor any agency Thereof, nor any of their employees, makes any warranty, express or implied, or assumes any legal liability or responsibility for the accuracy, completeness, or usefulness of any information, apparatus, product, or process disclosed, or represents that its use would not infringe privately owned rights. Reference herein to any specific commercial product, process, or service by trade name, trademark, manufacturer, or otherwise does not necessarily constitute or imply its endorsement, recommendation, or favoring by the United States Government or any agency thereof. The views and opinions of authors expressed herein do not necessarily state or reflect those of the United States Government or any agency thereof. 


\section{DISCLAIMER}

Portions of this document may be illegible in electronic image products. Images are produced from the best available original document. 


\section{Energy History \\ Chronology from World War II to the Present}

by:

Prentice C. Dean

August 1982
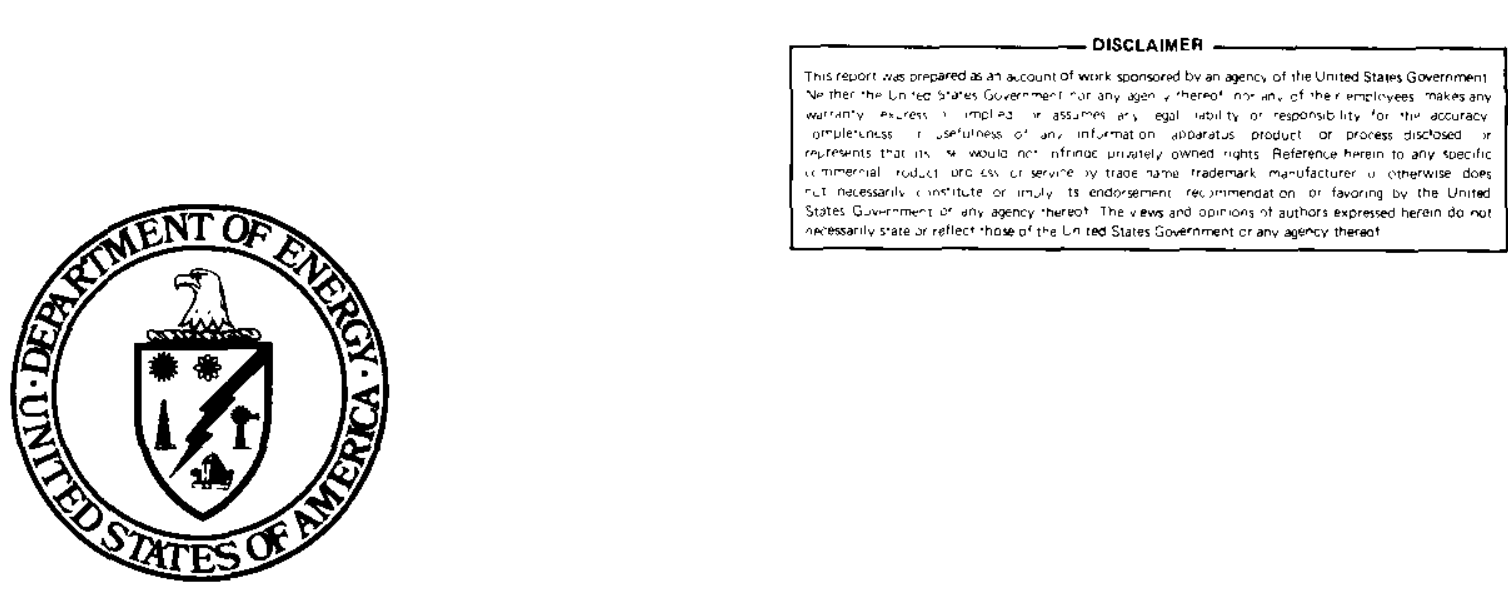


\section{INTRODUCTION}

The History Division of the U. S. Department of Energy has compiled an Energy History Chronology fram World War II to the Present to provide a basic guide to the major Presidential, Legislative, Judicial, and Federal agency actions relating to energy policy, research, development, and regulation in recent years. The chronology is arranged synoptically, allowing users to reference easily the historical context in which each event occurred. Surmaries of Presidential, Legislative, and Judicial actions relating to energy, rosters of federal energy officials, and a genealogy of federal energy agencies are also provided in separate appendices following the Chronology.

The Energy History Chronology was prepared in conjunction with the History Division's series of pamphlets on the Institutional Origins of the Department of Energy. The series includes concise histories of the Department of Energy, the Energy Research and Development Administration, the Federal Energy Administration, and the Atanic Energy Commission. All significant events and achievements noted in the institutional history are also listed in the Chronology.

Prentice Dean is a trained historian working in the History Division. He has compiled the Chronology with care, and has attempted to be as comprehensive as possible. Nevertheless, he would welcame suggestions for additions which add further to our understanding of the Nation's energy history since World War II.

Jack M. Holl

Chief Historian (Acting) 
ENERGY HISTORY CHRONOLOGY . . . . . . . . . . . . . . . . . 1

APPENDIX ONE

PRESIDENTIAL ACTIONS REIATED TO ENERGY . . . . . . . . . . 73

APPENDIX TWO

ENERGY RELATED LEGISLATION . . . . . . . . . . . . . 81

APPENDIX THREE

JUDICIAL DECISIONS REIATED TO ENERGY . . . . . . . . . . 91

APPENDIX FOUR

FEDERAL ENERGY OFFICIALS . . . . . . . . . . . . . 93

ATOMIC ENERGY COMMISSION . . . . . . . . . . . . . 93

DEPARTMENT OF ENERGY • . . . . . . . . . . . . . . 95

ENERGY RESEARCH AND DEVEIOPMENT ADMTNISTRATION . . . . . . . . 96

FEDERAL ENERGY ADMINISTRATION . . . . . . . . . . . . . . 96

FEDERAL ENERGY OFFICE . . . . . . . . . . . . . . 97

FEDERAL ENERGY REGULATORY COMMISSION

(Formerly FEDERAL POWER COMMISSION) . . . . . . . . . 97

DEPARTMENT OF INIERTOR . . . . . . . . . . . . . . 100

NUCLEAR REGULATORY COMMISSION . . . . . . . . . . . . 102

GENFALOGY OF FEDERAL ENERGY AGENCIES . . . . . . . . . . . 104 
DATE

UNTTED STATES AND WORLD EVENIS
PRESIDENTIAL, LEGISLATIVE, AND JUDICIAL ACTIONS
AGENCY ACTIONS
1945

April 12 Franklin D. Roosevelt died in Warm Springs, Georgia. VicePresident Harry S. Truman became President.

April 25

The United Nations Charter signed by fifty nations in San Francisco.

May 7

Nazi Germany surrendered to the United Nations sparking V-E Day celebrations in Europe and the United States.

July 7

Potsdam Conference began between President Truman, Prime Ministers Churchill and Atlee, and Premier Stalin.

July 16
First atomic bamb, "Trinity," detonated at Alamogordo, New Mexico, by the Manhattan

Engineer District (MED) of the Corps of Engineers, ("Manhattan Project"). 
$\underline{1945}$

UNITED STATES AND

WORID EVENTS

August 6

The first atomic bomb "Little Boy" dropped on Hiroshima, Japan.

August 9

August 14

"Fat Man" detonated over Nagasaki, Japan.

The government of Imperial Japan accepted the Potsdam Declaration and surrendered to the United Nations.

August 15

September 28

$\underline{1946}$

January 26

The United Nations General Assembly in London, created the United Nations Atamic Energy Commission.

April 1

Nationwide strike by 400,000 United Mine Workers.
PRESIDENIIAL, LEGISLATIVE, AND JUDICIAL ACTIONS

\section{AGENCY ACTIONS}

The Office of Price Administration lifted gasoline rationing in the United States.

Presidential Proclamation No.

2667 reserved offshore oil

rights for U.S. Government.

May 6

Division of Oil and Gas established in the Department of Interior. 
$\underline{1946}$

May 13

May 21

June-July

June 14
UNITED STATES AND WORTD EVENTS
PRESIDENTIAL, IEGISIATIVE, AND JUDICIAL ACTIONS

Federal Airport Act, provided federal aid for development of public airports.

President Truman ordered Secretary of Interior Julius Krug to take possession of the bituminous coal mines due to nationwide miners strike.

The Anmy's Manhattan Engineer District conducted Operation Crossroads, detonating two atomic weapons on the island of Bikini in the Marshall Islands, Pacific Ocean.

Bernard Baruch, U.S. delegate to the U.N. Atomic Energy Commission, proposed a plan to outlaw the manufacture of atomic bambs, dismantle those already existing, and share atomic energy secrets with other nations. The plan failed because the Soviet Union did not accept international inspection of their atomic facilities.

National Petroleum Council organized by Secretary of Interior Julius Krug. 
1946

July 16

August 1

$\underline{1947}$

1947-1948

January 1

March 12

President Truman proposed U.S. aid to Greece and Turkey, (the Truman Doctrine).

March 25

Coal mine disaster in Centralia, Illinois killed 111 miners.

United States oil imports exceed exports for the first time.
PRESIDENIIAI, LEGISIATIVE, AND JUDICIAL ACTIONS

President's Reorganization Plan No. 3 created Bureau of Land Management in the Department of Interior.

Atamic Energy Act, established the Atamic Energy Commission, and transferred the Army's Manhattan Engineer District atomic programs and facilities to the five nember conmission.

\section{AGENCY ACTIONS}

Atomic Energy Commission officially began operation, under Chairman David E. Lilienthal.

Atomic Energy Commission established Reactor Safeguards Committee to advise on reactor operation. 


\section{UNITED STATES AND} WORID EVENTS
PRESIDENTIAL, IEGISLATIVE, AND JUDICIAL ACTIONS

$\underline{1947}$

June 5 Plan for economic aid to Europe
proposed by Secretary of State George Marshall, later called the "Marshall Plan."
June 16

June 23

July 26
Interstate Natural Gas, Inc. v. Federal Power Commission; Supreme court extended FPC authority to all producers and gatherers of natural gas.

United States v. California; Supreme Court declared U.S. Government owns coastal tidelands (submerged lands).

National Security Act, unified all branches of the anmed services in a Department of Defense. The act also established the National Security Resources Board as an independent agency. In June 1949 the Board was transferred to Executive Office of the President. During the Korean Conflict, the head of the Office of

Defense Mobilization assumed all functions. 
UNITED STATES AND WORLD EVENTS

october

October 14

United States Air Force research plane, $\mathrm{X}-1$, became the first plane to exceed the speed of sound.

December 12

$\underline{1948}$

April-nay
PRESIDENTIAL, LEGISIATIVE, AND JUDICIAL ACTIONS

AGENCY ACTIONS

Atamic Energy Commission appointed Industrial Advisory Group under the chaimanship of James W. Parker of Detroit Edison Company to investigate peaceful uses of atomic energy.

The National Minerals Advisory Council organized on an informal basis to advise secretary of Interior on policies and programs relating to the minerals incustry in cooperation with the Bureau of Mines and Defense Minerals Administration. The Council disbanded on September 12, 1952.

Atomic Energy Commission conducted operation Sandstone, detonating three nuclear test weapons on the island of Enewetak in the

Marshall Islands, Pacific Ocean. 


\section{UNITED STATES AND} WORLD EVENTS

1948

May 14

May 14

State of Israel founded.

June 23

Total Berlin Blockade declared by the Soviet Union; lifted in Niay 1949.

June 29

June 30

November 2

Harry S. Truman elected President.
PRESIDENTIAL, LEGISLATIVE, AND JUDICIAL ACTIONS

\section{AGENCY ACTIONS}

By Department of Interior Order No. 2428 the National Bituminous Coal Advisory Council created to report to the Bureau of Mines Petroleum Imports Committee. The Council was dissolved by Order No. 2698, to take effect September 12, 1952.
Federal-Aid Highway Act, a series of amendments to the 1920 act, authorized appropriations for continued construction of highways.

Water Pollution Control Act, directed the Public Health Service of the Federal Security Agency and the Federal Works Agency to study pollution problems. The Act also established a Water Pollution Control Advisory Board. 


\section{9}

August 29

Soviet Union detonated their first atamic device.

September 30 The Conmunist forces in China, established the Peoples Republic of China.

$\underline{1950}$

January 3

January 31

March 21

May 10

June 25
PRESIDENTIAL, LEGISLATIVE, AND JUDICIAL ACTIONS

\section{AGENCY ACTIONS}

UNITED STATES AND WORID EVENTS 
UNITED STATES AND WORLD EVENIS

$\underline{1950}$

July 11

The Bituminous Coal Operators Association established.

September 3

September 8

October 17
PRESIDENTIAL， LEGISLATIVE， AND JUDICIAL ACTIONS

AGENCY ACTIONS

Gordon E. Dean became Chairman of Atamic Energy Commission.

Petroleum Administration for Defense (PAD) created in the Department of Interior by Order No. 2591 to mobilize petroleum and gas resources during Korean Conflict.

Defense Production Act, gave broad powers to the President and executive branch, including establishment of agencies to oversee production and distribution of energy products and resources for periods of emergency, such as the mobilization during Korean Conflict, and the 1973-74 oil embargo. 
1950

UNITED STATES AND WORLD EVENTS

November

November 26

Chinese troops entered the fighting in Korea.
PRESIDENIIAL, LEGISIATIVE, AND JUDICIAL ACTIONS
AGENCY ACTIONS

Atamic Energy Commission selected Aiken, South Carolina as site for new production reactors and approved construction of new gaseous diffusion complex near Paducah, Kentucky.

Department of Interior Order No. 2602 established the office of Assistant Secretary for Mineral Resources with 3 divisions: Minerals and Fuels, Geography, and Oil and Gas.

Defense Power Administration (later known as Defense Electric Power Administration), created by Secretary of Interior Order No. 2605, for Korean Conflict mobilization.

Defense Solid Fuels Administration created by Secretary of Interior Order No. 2605, for Korean Conflict mobilization.

Defense Minerals Administration created by Secretary of Interior Order No. 2605, for Korean Conflict mobilization. 
$\underline{1950}$

UNITED STATES AND WORID EVENTS
PRESIDENIIAL, LEGISLATIVE, AND JUDICIAL ACTIONS
AGENCY ACTIONS

December 16 President Truman issued a

Declaration of National Emergency

due to the fighting in Korea.

1951

January-February

Operation Ranger, the Atomic Energy Canmission's first nuclear test series in the Continental United States, conducted at the Nevada Test Site, 60 miles north of Las Vegas. Five test weapons were detonated.

January

February 21

March 9

U.S. DEPARTMENT OF ENERGY/HISTORY DIVISION
President's Materials Policy Commission (the Paley Commission) established. "Resources for Freedom," final report issued June 1952, forecast electric power and fuel demands.

The Defense Advisory Camittee on Coke and its By-Products established to advise the Defense Solid Fuels Administration on production, distribution, and problems of the coke industry during the wartime emergency.

Gas Industry Advisory Council established by the Secretary of Interior to provide advice for defense mobilization. 
1951

UNITED STATES AND WORLD EVENTS
PRESTDENITIAL, LEGISLATIVE, AND JUDICIAL ACTIONS
March 29

April-May

April

May 1

October-

November

December 20

December $21 \quad 191$ coal miners killed in West Frankfort, Illinois, leading to passage of the Federal Mine Safety Act of 1952.
Iran erupted in turmoil after the government announced the oil fields would be nationalized.

\section{Anglo-Iranian Oil Company} nationalized.

\section{AGENCY ACTIONS}

Military Petroleum Advisory Board established to study oil and gas problems in event of future war.

The Atomic Energy Commission conducted Operation Greenhouse at Enewetak, detonating four nuclear test weapons.
The Atamic Energy Comission conducted Operation Buster-Jangle at the Nevada Test Site, detonating seven nuclear test weapons.

First generation of electric power from a nuclear reactor (Experimental Breeder Reactor No. 1) occurred at the National Reactor Test Site in Idaho, under supervision of the Atamic Energy Camission. 


\section{2}

UNITED STATES AND

WORLD EVENTS

April-June

April 8

President Truman seized the steel mills to avoid a strike by 600,000 steel workers in a wage-price dispute. June 2 the Supreme court ruled the seizure unconstitutional, and on July 24 , the strike was settled.

June

July 16

November 1

November 4 Dwight D. Eisenhower elected President.
PRESIDENTIAL, LEGISLATIVE, AND JUDICIAL ACTIONS

The Atomic Energy Commission conducted operation TumblerSnapper at the Nevada Test Site, detonating eight nuclear test weapons.

University of California's Livermore Laboratory, now Lawrence Livermore National Laboratory, established.

Federal Coal Mine Safety Act directed all mines to comply with the Federal Mine Safety Code and authorized inspec-

tors to close unsafe mines.

The first thermonuclear device, code named "Mike," detonated by the Atamic Energy Commission at Enewetak. 
$\underline{1953}$

UNITED STATES AND WORID EVENTS

January 20

March-June

May 22

July 2

July 23 Anmistice agreed upon, ending hostilities in Korea.
PRESIDENTIAL, LEGISLATTVE, AND JUDICIAL ACTIONS

AGENCY ACTIONS

Executive Order NNo. 10426 set aside submerged lands on the continental shelf as a naval petroleum reserve under authority of Secretary of Navy.

The Atomic Energy Comission conducted Operation UpshotKnothole at the Nevada Test Site, detonating eleven nuclear test weapons.

Submerged Lands Act, gave states clear title to all lands within 3 miles of Atlantic and Pacific coasts and 10.5 miles of Gulf Coast. The act was supported by the new Eisenhower Administration and overruled the decision of U.S. v. California (1947) and' Truman's Executive Order of January 20, 1953.

Lewis L. Strauss became new Chairman of Atomic Energy Cammission. 
UNITED STATES AND WORLD EVENTSS

1953

August 7

August 9

Decenber 8

$\underline{1954}$

January 21

February-May

March 15

U.S. DEPARMMENT OF ENETRGY/HISTORY DIVISION
PRESIDENIIAL, LEGISLATIVE, AND JUDICIAL ACTIONS

AGENCY ACTIONS

Outer Continental Shelf Act, gave the Federal Government jurisdiction over the ocean floor beyond the $3 \mathrm{mile}$ boundary.

Establishment by Atamic Energy Cormission of Advisory Committee on Reactor Safeguards.

President Eisenhower delivered "Atams for Peace" speech before the United Nations.

U.S.S. Nautilus, the first nuclear powered submarine, launched by the Navy.

The Atamic Energy Camission conducted operation Castle at the Marshall Islands, detonating six nuclear test weapons, including shot "Bravo," of fifteen megatons, the largest announced U.S. nuclear test.
Alabama v. Texas; Supreme Court

upheld constitutionality of

Submerged Lands Act of 1953. 
UNITED STATES AND

WORLD EVENTS

April 30

May 7

The Vietminh captured the French fort of Dien Bien Phu in Vietnam; an armistice signed on July 21 , ending seven years of war.

June

June 7

August 13
PRESIDENTIAL, LEGISLATIVE, AND JUDICIAL ACTIONS

Termination of Petroleum Administration for Defense (PAD). Office of Oil and Gas assumed all functions of PAD.

President Eisenhower authorized a cabinet rank Advisory Committee on Energy Supplies and Resources Policy, chaired by the Director of the Office of Defense Mobilization. Report released on February $26,1955$.

Phillips v. Wisconsin; Supreme Court declared the Federal Power Commission had authority to set prices for natural gas including wholesales of natural gas.

Multiple Mineral Development Act, allowed for multiple use public lands. 
$\underline{1954}$

August 30

1955

January 10

February-May

May 14

U.S. DEPARTMENT OF ENERGY/HISTORY DIVISION
PRESIDENITAL, LEGISLATIVE,

AGENCY ACTIONS AND JUDICIAL ACTIONS

Atamic Energy Act of 1954, major revision of the 1946 Act gave added emphasis to development of peacetime uses of atamic energy, and encouraged private and public groups to build, own, and operate power reactors.

Atamic Energy Commission set up the Cooperative Power Demonstration Program, under which the Atamic Energy Commission and industry would cooperate in the construction and operation of experimental power reactors.

The Atamic Energy Camission conducted Operation Teapot at the Nevada Test Site, detonating fourteen nuclear test weapons.

The Atamic Energy Camission and Department of Defense conducted Operation Wigwam, an underwater nuclear test 500 miles southwest of San Diego, California. 
$\underline{1955}$

June 21

UNITED STATES AND WORLD EVENTS

August 4

August 8-20 The United States participated

in the first International

Conference on the Peaceful

Uses of Atomic Energy, in

Geneva, Switzerlană.

President Eisenhower proposed

mutual aerial inspection during

the United States, Great

Britain, France and the Soviet Union.

in the first International
Conference on the Peaceful
Uses of Atomic Energy, in

PRESIDENTIAL, LEGISLATTVE, AND JUDICIAL ACTIONS

Trade Agreements Extension Act, section 7, authorized the Director of the Office of Defense Mobilization to be responsible for advising the President when dependence upon imports of any "articles" impaired national security.

Atomic Energy Comminity Act, authorized local self-government, the transfer of municipal functions and sale of property at Richland, Washington, and Oak Ridge, Tennessee. 
December 5 American Federation of Labor and the Congress of Industrial Organizations merged, with a combined membership of 16 million workers.

\section{$\underline{1956}$}

February 17

February 22

April 11
Natural Gas Bill vetoed by President Eisenhower.

The bill would have provided independent producers of natural gas exemption from control by the Federal Power Commission.

Through President Eisenhower, the Atomic Energy Commission made available for sale or lease 20,000 kilograms of U-235 for use in power and research reactors abroad, and 20,000 kilograms for power reactors in the U.S.

Colorado River Storage Project Act, authorized construction of multipurpose water resource development projects. 
1956

UNITED STATES AND WORLD EVENTS

May-July

July 26

Egypt nationalized the Suez Canal.

August

August 24

The Independent Petroleum Association of America filed a petition with Director of the Office of Defense Mobilization to initiate an investigation, under authority of Section 7 of Trade Agreements Extension Act, to determine if oil imports threaten national security.
PRESIDENTIAL, LEGISLATTVE, AND JUDICIAL ACTIONS

\section{AGENCY ACTIONS}

The Atamic Energy Commission conducted Operation Redwing at the Marshall Islands, detonating seventeen nuclear test weapons, including the first air drop of a U.S. thermonuclear weapon.

National System of Interstate and Defense Highways Act, authorized a thirteen year program of highway construction

to be financed by various taxes.

Middle East Emergency Committee established in the Executive Office of the President to help alleviate oil shortages in Western Europe. 
UNITED STATES AND WORID EVENTS

October 23

The United Nations voted to establish the International Atamic Energy Agency to pramote peaceful uses of atomic energy.

October 29- Israel, Great Britain, and November 1 France attacked Egypt. A cease fire was proclaimed November 6 .

November 4

Soviet Union crushed

demonstrations in Hungary.

November 6

President Eisenhower won

re-election.

1957

April 23

May 1957-

March 1958
PRESIDENTIAL, IEGISLATIVE, AND JUDICIAL ACTIONS

The Director, Office of Defense Mobilization, as a result of a petition by Independent

Petroleum Association, reported to President Eisenhower that

oil imports threatened national security.

The Atamic Energy Cormission conducted Operation Plumbbob at the Nevada Test Site, detonating thirty-three nuclear test weapons, including shot

"Rainier," the first detonation contained underground. 
UNITED STATES AND WORLD EVENTS

June 26

July 29

September 2

Power from the Sodium Reactor Experiment at Santa Susana, California transmitted over the Southern California Edison System, marking the first cammercial use of power from a civilian reactor.

President Eisenhower signed the ratification of the International Atomic Energy Agency.
PRESIDENTIAL, LEGISIATIVE, AND JUDICIAL ACTIONS

President Eisenhower appointed a Special Committee to Investigate Crude Oil Imports. The Special Cammittee's report submitted on July 29, 1957.
Price-Anderson Act, provided financial protection to the public, Atanic Energy Commission licensees and contractors in the event of a major nuclear power plant accident.

October 1 International Atomic Energy Agency inaugurated in Vienna, Austria.

October 4 Soviet Union launched Sputnik, the first satellite to orbit earth. 
UNITED STATES AND WORLD EVENTS

$\underline{1957}$

Novermber

December 2 The pressurized water reactor at Shippingport went critical, fifteen years to the day after Enrico Fermi achieved the

first nuclear chain reaction.

on December 23 the reactor reached full net power rating of 60 megawatts of electricity, the first full-scale nuclear power plant in the United States.

$\underline{1958}$

January 1 Euratom (European Atamic Energy Community) officially estab-

lished. Members included Belgium, France, Federal Republic of

Germany, Italy, Luxembourg, and

the Netherlands.

February 1 The European Nuclear Energy

Agency established within the Organization for European

Economic Cooperation.
PRESIDENTIAL, LEGISLATIVE, AND JUDICIAL ACTIONS

President's Science Advisory Committee created by transfer of the Science Advisory Committee of the Office of Defense Mobilization to the Executive Office of the President. 


\section{$\underline{1958}$}

UNITED STATES AND

WORLD EVENTS

April-August

May 22

Keel of the world's first

nuclear powered merchant ship,

N.S. Savannah, laid at Camden, New Jersey. Ship launched on

July 21, 1959.

May 26

June 23

July 14
PRESIDENTIAL， LEGISLATIVE, AND JUDICIAL ACTIONS

AGENCY ACTIONS

The Atomic Energy Commission conducted Operation Hardtack I in the Marshall Islands, detonating thirty-five nuclear test weapons.
President Eisenhower dedicated Shippingport Atomic Power Station.

President Eisenhower sent to Congress a proposed international agreement with the European Atomic Energy Cormunity (Euratom) for joint development of U.S. type power reactors to provide six nations with installed capacity of one million kilowatts by 1963 .
John A. McCone became Chairman of the Atomic Energy Commission, replacing Lewis L. Strauss. 


\section{UNITED STATES AND} WORLD EVENTS

$\underline{1958}$

July 29

August-

September

August 23

Septernber-

October

September 1-3 The United States participated in the second United Nations International Conference

on the Peaceful Uses of Atamic Energy in Geneva, Switzerland.
PRESIDENITAL, LEGISIATIVE, AND JUDICIAL ACTIONS

AGENCY ACTIONS

National Aeronautics and Space Act, established National Aeronautics and Space Administration to conduct civilian aeronautical and space research.

The Atomic Energy Commission conducted Operation Argus in the South Atlantic, detonating 3 high altitude nuclear test weapons.

Federal Aviation Act, established the Federal Aviation Administration to regulate air transportation.
The Atomic Energy Cormission conducted Operation Hardtack II at the Nevada Test Site, detonating thirty-six nuclear test weapons. 
UNITED STATES AND WORLD EVENIS
PRESIDENTIAL, LEGISIATIVE, AND JUDICIAL ACTIONS
AGENCY ACTIONS
November

1958-

September

1961

November 8

March 10

March 13

April 22

1959

13
The United States, Great Britain, and Soviet Union agreed to a moratorium on atmospheric nuclear testing, as negotiations continued for a definitive agreement.

United States signed an agreement with Euratom to cooperate and exchange atomic materials and information for research.

April 22
The Inter-American Nuclear Energy Commission established.
Presidential Proclamation No. 3279 established Mandatory Oil Import Program, to limit low price imported oil and stimulate development of domestic production and refining capacity through quotas.
Oil Import Administration established in Department of Interior to administer the Mandatory Oil Import Program. 


\section{UNITED STATES AND} WORID EVENTS

1959

August 14

September

$15-27$

November 24

Soviet Premier Khrushchev visited the United States.

December 30 U.S.S. George Washington commissioned, the first nuclear submarine to carry and launch Polaris Intercontinental Ballistic Missiles (ICBM).

1960

January 14

John L. Lewis, President of the United Mine Workers since 1920, retired.

May 1
PRESIDENTIAL, LEGISLATIVE, AND JUDICIAL ACTIONS

Executive Order No. 10831 established the Federal Radiation Council.

\section{AGENCY ACTIONS}

A Memorandum of Cooperation between the United States and Soviet Union signed by Atomic Energy Cammission Chairman John MoCone and Professor Vasily S. Emelyanov, Head of the USSR Main Administration for Utilization of Atomic Energy. 


\section{$\underline{1960}$}

May 16

July 7

November 8

John F. Kennedy elected

President.

1961

February 1 United States launched Minuteman $I$, the first Intercontinental Ballistic Missile.

March 1

Mid-1961
PRESIDENTIAL, LEGISIATIVE, AND JUDICIAL ACTIONS

AGENCY ACTIONS

\section{WORTD EVENTS}

Sumit Conference with United States, Great Britain, France and Soviet Union opened in Paris, France. On May 17 the conference broke up because of the U-2 incident.
Coal Research Act, established the Office of Coal Research in the Department of Interior.
Glenn $\mathrm{T}$. Seaborg named by President Kennedy to be Chairman of the Atomic Energy Commission to fill the unexpired term of John A. MoCone.

Seaborg remained Chaiman until August 16, 1971.

The Office of Civil and Defense Mobilization redesignated as the Office of Emergency Planning. 
UNTTED STATES AND

WORID EVENTS

1961

June

President Kennedy and Premier Khrushchev met in Vienna, Austria.

August

September 1 Soviet Union broke nuclear test moratorium and began atmospheric testing. On October 23 and 30 they tested nuclear weapons of thirty and fifty megatons.

September 5

September 1961-

June 1962
PRESIDENIIAL, IEGISLATTVE, AND JUDICIAL ACTIONS
AGENCY ACTIONS

Senate Committee on Interior and Insular Affairs estab-

lished The National Fuels and

Energy Study Group which campleted

its report on September 7, 1962.

President Kennedy ordered resumption of underground nuclear testing following atmospheric nuclear

tests by the Soviet Union.

The Atomic Energy Cammission conducted Operation Nougat at the Nevada Test Site, the first nuclear weapon test series since the end of the test moratorium. There were thirty-two tests, including shot "Gnome," the first Peaceful Nuclear Explosion (as part of Project Plowshare), detonated in a salt cavity in Carlsbad, New Mexico. 
1961

December 2

1962

February 20

John H. Glenn, Jr., first U.S. astronaut to enter orbit, circled the earth three times.
PRESIDENTIAL, LEGISLATTVE, AND JUDICIAL ACTIONS

The Petroleum Study Camittee, established by President Kennedy, instructed the director, Office of Emergency Planning, to lead a study of petroleum requirements in relation to national

security. Report issued on September 4, 1962.
March 17

April 24

April-

November
President Kennedy asked Atamic Energy Commission Chairman Glenn T. Seaborg to report on the role of nuclear power in the econany. The Chairman submitted the report on November 20, 1962.

President Kennedy authorized U.S. resumption of atmospheric nuclear testing.
The Atonic Energy Commission conducted Operation Daminic I in the Christmas Island and Johnston Island areas of the Pacific Ocean. This was the last U.S. atmospheric test series. 


\section{UNITED STATES AND WORLD EVENTS}

$\underline{1962}$

June 8

July 1962-

June 1963

October 11

October 23 Cuban Missile Crisis declared by President Kennedy, who announced the Soviet Union had been building missile and bomber bases in Cuba, and the U.S. would quarantine the island. The Blockade was lifted on November 20 .
PRESIDENIIAL, LEGISLATTVE, AND JUDICIAL ACTIONS

AGENCY ACIIONS

President Kennedy created the Office of Science and Technology in the Executive Office of the President.

The Atamic Energy Commission conducted Operation Storax at the Nevada Test Site; all tests wereunderground. Operation Daminic II, conducted at the NTS during July 1962, was the last series to test above ground in the United States.
Trade Expansion Act, authorized the President to impose mandatory oil import quotas. 
$\underline{1963}$

February 15

August 5

November 1-2 Military coup overthrew the government of President Diem in South Vietnam.

November 22 President Kennedy assassinated in Dallas, Texas, and VicePresident Lyndon Johnson became President.

December 17

PRESIDENITAL, LEGISIATIVE,

AND JUDICIAL ACTIONS

WORTD EVENTS

An Interdepartmental Energy Study Group, chaired by the Director, Office of Science and Technology, directed a camprehensive study of energy resources. The report campleted June 1964.

The Limited Nuclear Test Ban Treaty, signed by the United States, Great Britain, and Soviet Union, banned nuclear tests in the oceans, atmosphere, and outer space. The Treaty took effect in November 1963.
Clean Air Act, provided assistance to states and local governments to research air pollution problems. Major amendments were made to the act in 1970 . 


\section{UNITED STATES AND}

WORID EVENIS

1964

June 24

August 2

"Gulf of Tonkin" resolution passed by Congress, allowing President Johnson to send armed forces to Vietnam.

August 26

August $30-$ September 10

Third United Nations International Conference on the Peaceful Uses of Atamic Energy conducted in Geneva,

Switzerland.

September 3

November 3 Lyndon Johnson elected President.
PRESIDENTIAL, LEGISLATIVE,

AND JUDICIAL ACTIONS

A Cabinet Committee on Appalachian coal established by President Johnson.
Private Ownership of Special Nuclear Materials Act, allowed the power industry to own fuel for power reactors. After June 30, 1973 private ownership of power reactor fuels would become mandatory.

Wilderness Act, established the National Wilderness Preservation System, which would ultimately prohibit mining activity on designated lands. 
1964

December 16

1965

June 5

State Department announced

U.S. troops were participating

directly in the fighting in

Vietnam; no longer acting solely

as advisors.

August 12-17 Rlots occurred in the Watts area of Ios Angeles; 35 people were killed.

October 2

October 20
PRESIDENTIAL, IEGISIATIVE, AND JUDICIAL ACTIONS

\section{AGENCY ACTIONS}

Atamic Energy Camission issued a permit to Jersey Central Power and Light Company for

construction of a nuclear power plant at Oyster Creek, New Jersey. This was the first civilian power reactor to be built on a competitive basis with conventional plants and without Government assistance.

Water Quality Act, established the Federal Water Pollution Control Administration in Department of Health, Education and Welfare.

Solid Waste Disposal Act, provided assistance to public and private agencies for study, collection and disposal of solid waste. 


\section{$\underline{1965}$}

November 9

December 29

1966

January 17

United States B-52 bomber crashed over the coast of Spain carrying four unarmed thermonuclear bombs. Three land on the ground and one is retrieved from the ocean.

April 27

September 16

The first major power blackout covered the northeast U.S.

Scenic Hudson Preservation Conference v. Federal Power Cormission; U.S. Court of Appeals for the Second Circuit ruled the FPC was a public body and therefore must vigorously advance the public's interest.

\section{AND JUDICIAL ACTIONS}


$\underline{1966}$

October 15

UNITED STATES AND

WORLD EVENTS

1967

June 5

June 17

June 23-25 Arab nations closed the Suez

Iranian pipelines, and both events created an oil supply emergency.

Peoples Republic of China

President Johnson and Premier
PRESIDENTIAL, LEGISLATIVE,

AND JUDICIAL ACTIONS

Department of Transportation Act, established the Department of Transportation and gave DOT responsibility for pipeline safety standard setting and enforcement. The act also transferred Interstate Commerce Cammission authority over surface transport of fuels to DOT. between Israel and surrounding

Canal. The Shah of Iran closed exploded a thermomuclear device. Kosygin of the Soviet Union held talks in Glassboro, New Jersey. 


\section{$\underline{1967}$}

November 21

November 25

$\underline{1968}$

March 31

President Johnson announced a bambing halt in North Vietnam and the start of peace talks in Paris, France. He also announced he would not run for re-election.

April 26

August 12
PRESIDENIIAL, LEGISLATIVE, AND JUDICIAL ACTIONS

\section{AGENCY ACTIONS}

Air Quality Act, strengthened the Clean Air Act of 1963 with additional funding. Title II of the Air Quality Act, the National Emission Standards Act, gave authority to the Secretary of

Health, Education and Welfare

to set auto emission standards.

An Energy Policy Staff established in the Office of Science and Technology.

Natural Gas Pipeline Safety Act, set standards for pipeline safety.
Atomic Energy Cormission detonated shot "Boxcar," the largest thermonuclear weapon in the United States, 3,800 feet below ground. 
38 


\section{9}

February 20

July 20

August 18

September 14 Oil tanker S.S. Manhattan completed journey along

Northwest Passage.

December 30

Two United States astronauts and Edwin Aldrin, landed on the heaters as part of the Passive Seismic Experiment Package to produce heat for the instruments during the cold lunar night.
UNITED STATES AND WORLD EVENTS
PRESIDENTIAL, LEGISIATIVE, AND JUDICIAL ACTIONS

\section{AGENCY ACTIONS}

A Cabinet Task Force on Oil Import Control established to review the mandatory oil import program. Submitted a report to President Nixon on February 2, 1970. aboard Apollo 11, Neil Arrnstrong, moon, carrying two plutonium 238

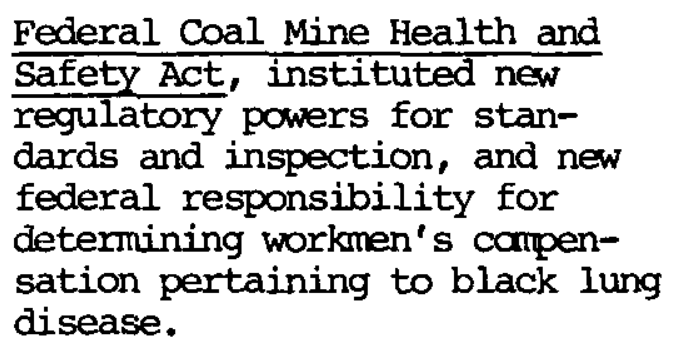

Federal Coal Mine Health and Safety Act, instituted new regulatory powers for standards and inspection, and new federal responsibility for determining workmen's compensation pertaining to black lung disease. established the Atamic Safety and Licensing Appeal Board. 


\section{9}

December 30

$\underline{1970}$

January 5

United Mine Worker official Joseph A. Yablonski, his wife and daughter found shot in their home in Clarksville, Pennsylvania.

January 29

February 20
PRESIDENTIAL, LEGISIATIVE, AND JUDICIAL ACTIONS

Tax Reform Act, reduced the depletion allowance on oil from $27 \frac{1}{2}$ percent to 22 percent.

President Nixon appointed Russell E. Train, then Under Secretary of Interior, as Chairman of the Council on Environmental Quality. The other members were Robert Cahn and Gordon J. F. MacDonald. The Council submitted its first annual report to Congress in August 1970.

An Oil Policy Comittee established under direction of General Iincoln, head of the Office of Emergency Preparedness. 


\section{UNITED STATES AND WORID EVENTS}

1970

February 5

March 5

April 3

U.S. DEPARTMENT OF ENERGY/HISTORY DIVISION

Ratification of the Treaty for the Non-Proliferation of Nuclear Weapons, by the U.S., U.K., and U.S.S.R.,
PRESIDENTIAL, IEGISLATTVE, AND JUDICIAL ACTIONS

\section{AGENCY ACTIONS}

Executive Order No. 11507, "Prevention, Control and Abatement of Air and Water Pollution," established guidelines for control of pollution from federal facilities and projects. and forty-five other nations.

Executive Order No. 11514 reinforced the National Environmental Policy Act; ordered federal agencies to monitor and evaluate activities for the protection of the environment, and gave additional broad powers to the council on Environmental Quality.

Water Quality Improvement Act and Title II of the act, the Environmental Quality Improvement Act, authorized an Office of Environmental Quality in the Executive Office of the President, to provide professional and administrative support to the Council on Envirommental quality, and to institute new measures to control wastes, particularly oil, fram entering bodies of water. 
April 22

Millions of Americans participated in anti-pollution demonstrations to mark the first "Earth Day."

May

President Nixon announced U.S. troops entered Cambodia to close off North Vietnamese supply routes. Many college campuses held protest demonstrations and four students were killed at Kent State University in Ohio by National Guardsmen.

President Nixon sent to Congress Reorganization Plan No. 3, which created the Environmental Protection Agency from components of the Departments of Interior;

Health, Education, and Welfare; Agriculture; and the Atomic Energy Cammission. The Plan abolished Federal Water Quality Administration (Interior) and Federal Radiation Council (HEW) . 
UNITED STATES AND WORLD EVENTS

1970

July 9

August 6

Septenber

September 23 Electric power "brownouts".hit northeast during heat wave.

october 21
October 26

octaber 26
PRESIDENIIAL, LEGISLATIVE, AND JUDICIAL ACTIONS

President Nixon sent to Congress Reorganization Plan No. 4, which established as of Octaber 2, 1970 the National. Oceanic and Atmospheric Administration in the Department of Commerce.

The Domestic Council established an Energy Subcammittee.

General Lincoln of the Office of Emergency Preparedness set up a Joint Board on Fuel Supply and Transportation.
Merchant Marine Act Amendment, allowed the Federal Government to provide subsidies to finance construction of oil tankers and liquid natural gas transport vessels.

Resource Recovery Act, amended the Solid Waste Disposal Act and provided financial assistance to states and local governments to construct disposal facilities. 
1970

December 24

December 31

1971

June 4

June
UNITED STATES AND WORID EVENTS
PRESIDENTIAL, IEGISIATIVE, AND JUDICIAL ACTIONS
AGENCY ACTIONS

Geothermal Steam Act, authorized issuance of leases for development of geothermal steam.

Clean Air Amendments, set numerous emission standards, including those for autamobiles.

In his first message to Congress on energy policy, President Nixon proposed a new Department of Natural Resources, consolidating all federal energy resource and development programs.

U.S. Advisory Camittee on Energy to the Secretary of Interior (Dr. John J. Mcketta, Chairman), composed of representatives from oil, gas, coal, and electric industries, sent report to secretary of Interior endorsing the plan to create a Department of Natural Resources. 


\section{UNITED STATES AND} WORLD EVENTS

1971

July 23

August 15

President Nixon imposed New Economic Policy using wage and price controls for the

first time since World War II. The dollar was devalued by cutting the tie with gold.
PRESIDENTIAL, LEGISIATIVE, AND JUDICIAL ACTIONS

Calvert Cliffs coordinating

Committee v. Atomic Energy

Commission; D.C. Court of

Appeals ruled that Atomic

Energy Commission regulations

did not comply with National

Environmental Policy Act of

1969, and obligated the Commission

to incorporate wider environ-

mental concerns in its regulatory

program and licensing

procedures.

August 17

James R. Schlesinger became

Chairman of the Atomic Energy

Commission. 
1972

January 13

February 21 President Nixon arrived in Peking, China for an eight day visit and later pledged a

"normalization of relations."

April 3

May 22
UNITED STATES AND WORID EVENTS
President Nixon, in the first
PRESIDENTIAL, LEGISIATIVE, AND JUDICIAL ACTIONS

Natural Resources Defense Council v. Morton; D.C. Circuit Court of Appeals prohibited a Department of Interior sale of leases to 300,000 acres on the outer continental shelf. Environmental groups charged the government's environmental impact statement for the sale was inadequate because it did not mention alternative sources of oil to prevent the danger of oil spills.

Northern States Power Company v. Minnesota; Supreme Court granted the Federal Government preemption over the states to regulate radiation control standards for nuclear power plants. visit of a U.S. President to Moscow, held summit talks and signed the SALT I agreement. 


\section{UNITED ST'ATES AND} WORLD EVENTS
Police arrested five men in the Democrat National Comittee headquarters in the Watergate office complex in Washington, D.C.

August 7

November 7

President Nixon reelected President.

1973

January

January

North and South Vietnam and the United States signed a Peace Treaty, "officially" ending the Vietnam Conflict and active U.S. participation.

January 11 Phase III of the Economic Stabilization Program began.
PRESIDENTIAL, LEGISIATIVE, AND JUDICIAL ACTIONS
Atomic Energy Conmission Chairman James R. Schlesinger announced a cooperative agreement with industry to build

the demonstration Liquid Metal Fast Breeder Reactor, on the Clinch River in Tennessee.

President Nixon appointed

a Counsellor to the President for Natural Resources, to coordinate domestic natural resources, environment, and energy matters. 
UNITED STATES AND WORID EVENTS
PRESIDENTIAL, LEGISLATIVE, AND JUDICIAL ACTIONS
February 6

February 7

Apral 18

April 18
Atamic Energy Commissioner Dixy Lee Ray designated Chainman.

Executive Reorganization Plan No. 1 abolished the Office of Emergency Preparedness and the Office of Science and Technology. The OST's functions were transferred to the

National Science Foundation. The Plan also transferred the oil import program to the Office of Deputy Secretary of Treasury William Simon.

The reorganization plan went into effect on July 1, 1973.

Executive Order No. 11712 established National Energy Office in the Executive Office of the President and a Special Committee on Energy, composed of the Advisor to the President for National Security (Henry Kissinger), Domestic Affairs Advisor (John Ehrlichman) and Secretary of Treasury (George Shultz).

The Executive Order also ended the oil import quota system and substituted an import fee of

1 cent per gallon on crude oil. 
UNITED STATES AND

WORID EVENTS

$\underline{1973}$

April 18

April 30

June

President Nixon imposed a 60 day freeze on prices.

June 16-25

June 29

Soviet leader Brezhnev visited

the United States.

PRESIDENTIAL, LEGISLATIVE, AND JUDICIAL ACTIONS

President Nixon directed that a new post of Assistant Secretary for Energy and Minerals be created in the Department of Interior, and an office of Energy Conservation.

Econariic Stabilization Act Amendments, authorized fuel allocations.

Executive Order No. 11726

cambined the Special Energy

Committee and National Energy

Office in an expanded Energy

Policy Office within the

Executive Office of the Pres-

ident to formulate and

coordinate energy policy at

the presidential level. Former

Governor Love of Colorado

named head of the Office

and Assistant to the

President. Love resigned on

December 3, 1973. 
1973

June 29

June 29

Summer The Senate Special Conmittee to Investigate Campaign Practices in 1972 held hearings in Washington D.C. Numerous allegations were made that high administration officials conducted a cover-up of the "Watergate" incident.

October 2

October 6

"Yom Kippur" war broke out in Middle East between Israel, Egypt, and Syria.
PRESIDENTIAL, LEGISLATTVE, AND JUDICIAL ACTIONS

AGENCY ACTIONS

President Nixon proposed

creation of an Energy Research and Development Administration.

The new agency would include all functions of Atomic Energy

Conmission, except licensing and regulatory responsibilities, which would be placed under a separate Nuclear Energy Commission.

President Nixon again proposed a new Department of Energy and Natural Resources.
The Energy Policy Office announced establishment of a mandatory allocation program for home heating oil and propane gas. 


\section{UNITED STATES AND WORTD EVENTS}

$\underline{1973}$

October 11

October 17 Organization of Arab Petroleum Exporting Countries embargoed oil to the United States and Netherlands because of their support for Israel.

November 7

November 12

U.S. DEPARTIENT OF ENERGY/HISTORY DIVISION
PRESIDENTIAL, LEGISIATTVE, AND JUDICIAL ACTIONS

AGENCY ACTIONS

President Nixon established an Energy Research and Development Advisory Council, composed of leading experts in various areas of energy research outside government, to report to the Energy Policy Office.

President Nixon gave first address to the Nation since oil embargo, and called for Project Independence (selfsufficiency from foreign supplied petroleum by 1980), a return to daylight savings time, and the passage of previously proposed legislation.

An Energy Emergency Action Group, headed by chief Energy Advisor John Love, established. 


\section{3}

UNITED STATES AND WORID EVENIS

November 25

November 27

Winter 19731974

December 1
Petroleum shortages in many areas of the U.S. forced consumers to wait in lines to buy gasoline.
PRESIDENIIAL, LEGISLATIVE, AND JUDICIAL ACTIONS

AGENCY ACTIONS

President Nixon, after an address to the Nation on energy, announced several actions under authority of the Econamic Stabilization Act of 1970 and Defense Production Act of 1950. Included were new or extended allocation programs for middle distillates, gasoline, and jet fuels, and regulations for halting power plants and industries switching from coal to oil.

Emergency Petroleum Allocation Act, provided authority for a mandatory oil allocation program run by the Energy Policy Office.
Dixy Lee Ray, Chairman of the Atamic Energy Commission, released a report, "The Nation's Energy Future," as requested by President Nixon on June 29, which called for establishment of an Energy Research and Development Administration. 
UNITED STATES AND

WORLD EVENTS

1973

December 4

December 6

Gerald R. Ford sworn in as Vice-President following resignation of Spiro Agnew October 10.

December 15

March 6

March 17

Embargo of oil from Organization of Arab Petroleum Exporting Countries to the United States and

Netherlands ended.
PRESIDENTIAL, LEGISLATIVE, AND JUDICIAL ACTIONS

Executive Order №. 11748 established the Federal Energy Office in the Executive Office of the

President. William E. Simon named Executive Director of

the Energy Emergency Action

Group. President Nixon assumed chaimanship of the Group.

Emergency Daylight Saving Time Energy Conservation Act, required a return to daylight saving time through April 1975.

William Simon named Administrator, Federal Energy Office.

National Energy Emergency Act vetoed by President Nixon.

April 17

John Sawhill named Administrator, Federal Energy Office. 
1974

May 7

May 18

June 22

India detonated a "peaceful" nuclear device.

NITED STATES AND

WORID EVENTS

PRESIDENITIAL, LEGISIATIVE,

AND JUDICIAL ACTIONS

Federal Energy Administration Act, established the Federal

Energy Administration, incorpo-

rating the Federal Energy Office.

Energy Supply and Envirommental Coordination Act, authorized the Federal Fnergy Adninistration to order electric generating utilities and industrial fuel burning installations to convert from oil and gas to coal, and amended the Clean Air Act's emission standards for automobiles.

August 9 President Nixon resigned and Vice-President Gerald R. Ford became President.

Septermber 3

Geothermal Energy Research, Development, and Demonstration Act, authorized the Geothermal Energy Coordination and Management Project, including members from National Aeronautics and Space Administration, Atomic Energy Commission, and National Science Foundation. Activities of project transferred to Energy Research and Development Administration. The act also established the Geothermal Resources Development Fund. 
UNITED STATES AND

WORID EVENTS

1974

September 3

October 5

October 8

October 11

October 25

U.S. DEPARTMENT OF ENERGY/HISTORY DIVISION
PRESIDENTIAL, IEGISLATTVE, AND JUDICIAL ACTIONS

Solar Heating and cooling Demonstration Act, authorized

National Aeronautics and Space

Administration to conduct research,

development and manufacture of

solar heating and cooling

equipment with assistance from

Department of Housing and Urban

Development.

Daylight Saving Time Energy

Conservation Act Repeal, from

the last Sunday in October

1974 through the last Sunday

in April 1975.

Executive Order №. 11814

established the Energy Resources

Board, later called Energy

Resources Council, to be headed

by Rogers Morton, with Frank

Zarb as Executive Director.

Energy Reorganization Act, abolished the Atanic Energy

Cormission and created the Energy

Research and Development Admin-

istration and Nuclear Regulatory

Commission.

John Sawhill, Administrator of Federal Energy Administration, resigned. 
UNITED STATES AND WORLD EVENTS

October 26

November 15 Under the International Energy Agency, the major oil consuming nations, including U.S., Canada, Japan, and fifteen European nations, began to coordinate their short term response to future energy problems through an oil sharing agreement and plan for long term efforts to reduce dependence on imported oil. The Agency was placed in the Organization of Econamic Cooperation and Development, in Paris, France.
PRESIDENTIAL, LEGISIATTVE, AND JUDICIAL ACTIONS

AGENCY ACTIONS

Solar Energy Research, Develop-

ment and Demonstration Act, authorized the Solar Energy

Coordination and Management

Project, including members from

National Science Foundation,

Department of Housing and Urban

Development, Federal Power Com-

mission, and National Aeronautics and

Space Administration, to coordinate

research in solar energy.

Activities of project transferred

to Energy Research and Development

Administration. The act also

authorized establishment

of the Solar Energy Research

Institute.
Federal Energy Administration released "Project Independence, A Summary." 
UNITED STATES AND WORLD EVENTS

\section{$\underline{1974}$}

November 25

December 5

December 31

1975

January 4

January 19

February 7
PRESIDENTIAL, LEGISLATIVE,

AGENCY ACTIONS

AND JUDICIAL ACTIONS

Frank Zarbo named Administrator, Federal Energy Administration.

Extension of Emergency

Petroleum Allocation Act of 1973 until August 31, 1975.

Federal Non-Nuclear Energy

Research and Development Act, required the administrator of

the Energy Research and Development Administration to submit to

Congress annually a comprehensive plan for energy research, development, and demonstration.

Federal-Aid Highway Act, established the 55 mph speed limit.

Energy Research and Development Administration activated and Robert C. Seamans, Jr., named Administrator.

Energy Research and Development Administration sponsored the first hot water project in southern Idaho as part of the geothermal development program. 
1975

March 17

April 30

May 20

June 28

July 21

September 9

September 29
UNITED STATES AND WORLD EVENTS

PRESIDENTIAL, LEGISLATIVE, AND JUDICIAL ACTIONS

AGENCY ACTIONS

United States v. Maine; Supreme

Court ruled states do not have jurisdiction over and possession of the entire outer continental shelf.

The Republic of South Vietnam fell to the North Vietnamese.

The Surface Mining Control and Reclamation Act vetoed by President Ford.

Energy Research and Development Administration's first national energy plan "Creating Energy Choices for the Future," presented to the President.

The Petroleum Price Review Act vetoed by President Ford.

President Ford vetoed legislation extending damestic oil price controls for additional six months.

The Emergency Petroleum Allocation Act, which expired August 31, was extended until November 15. 


\section{UNITED STATES AND} WORLD EVENTS

1975

October 29

Decermber 22

1976

January 12

April 5

April 15
PRESIDENIIAL, IFGISLATIVE, AND JUDICIAL ACTIONS

\section{AGENCY ACTIONS}

Energy Research and Development Administration dedicated their first prototype wind power system at Sandusky, Ohio.

Energy Policy and Conservation Act, established the Strategic Petroleum Reserve.

Energy Research and Development Administration announced first operation of Princeton Large Torus, largest tokanak fusion device in United States.

Naval Petroleum Reserves Production Act, authorized Department of Interior to establish national petroleum reserves and prepare plans for future production of existing naval reserves. The act also authorized exploration of Petroleum Reserve No. 4 in Alaska.

Energy Research and Development Administration released "Creating Energy Choices for the Future," first annual update of national energy plan for research, development, and demonstration. 
May

June 4

July 3

July 4

United States celebrated its

bicentennial.

August 14

August 14
UNITED STATES AND WORLD EVENTS
PRESIDENTIAL, IEGISLATIVE, AND JUDICIAL ACTIONS

Energy Research and Development Administration assumed responsibility for management of the Clinch River Breeder Reactor, the Nation's first large scale demonstration breeder reactor, in Oak Ridge, Tennessee.

Experimental 10 megawatt geothermal test loop facility dedicated at Niland, California, under auspices of the Energy Research and Development Administration.

Federal Coal Leasing Amendment Act vetoed by President Ford.

Energy Conservation and Production Act, authorized continuation of the Federal Energy Administration and provided incentives for damestic energy production.

Energy Conservation Standards for New Buildings Act, established energy conservation standards for new buildings program in the Department of Housing and Urban Development. 


\section{UNITED STATES AND WORID EVENTS}

1976

November 2

Jimmy Carter elected President.

November 23

Winter 19761977

1977

February 2

February 7

March 24

April 7

U.S. DEPARIMENT OF ENERGY/HISTORY DIVISION
PRESIDENTIAL, LEGISLATIVE, AND JUDICIAL ACTIONS

\section{AGENCY ACTIONS}

Energy Research and Development Administration selected Clayton, New Mexico as site for 200

kilowatt wind turbine.

Emergency Natural Gas Act, provided special allocation programs to aid in the supply emergency.

John F. O'Leary named Administrator, Federal Energy Administration.

Golden, Colorado selected as site for Solar Energy Research Institute (SERI), to be managed by Midwest Research Institute.

President Carter announced the United States will defer indefinitely the reprocessing of spent fuel fram civilian reactors, and delay the construction of the Clinch River Breeder Reactor. 
UNITED STATES AND WORID EVENTS

April 29

July 5

July 13 New York City suffered a power blackout.

July 28 First oil from Alaska's Prudhoe Bay delivered from the 799 mile pipeline.

August 3

June 23
PRESIDENTIAL, LEGISIATIVE, AND JUDICIAL ACTIONS

AGENCY ACTIONS

President Carter submitted to Congress National Energy Plan I, and called for a new, consolidated cabinet level Department of Energy.

Energy Research and Development Administration released "A National Plan for Energy Research, and Demonstration."

Solar Energy Research Institute began operation.

Surface Mining Control and Reclamation Act, regulated surface coal mining operations and established the office of Surface Mining Reclamation and Enforcement in the Department of Interior. 
UNITED STATES AND WORLD EVENTS

1977

August 4

August 5

October 1

October

Project Agreement for cooperation in the Field of Solar Energy (SOLERAS) signed between U.S. and Saudia Arabia, providing for a five year $\$ 100$ million jointly funded solar energy research and development project.

1978

January 24

Soviet spy satellite containing a nuclear reactor broke-up over northwest Canada.

March 10

U.S. DEPARTMENT OF ENERGY/HISTORY DIVISION
PRESIDENTIAL, LEGISIATTVE, AND JUDICIAL ACTIONS

\section{AGENCY ACTIONS}

Department of Energy Act, abolished Energy Research

and Development Administration,

and Federal Energy Administration,

and transferred their functions,

to new Department of Energy.
James R. Schlesinger nominated as first Secretary of Energy.

Department of Energy activated.

Nuclear Non-Proliferation Act, authorized the President to pursue international studies on proliferation of nuclear materials and encouraged nations to sign Treaty

on the Non-Proliferation of Nuclear Weapons. 


\section{8}

UNITED STATES AND

WORLD EVENTS

April 4

United Mine Workers ended 105

day strike by 160,000 miners.

September 17 Camp David Accord signed in Washington, D.C. by Egypt and Israel.

September 27

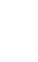

PRESIDENTIAL， LEGISLATIVE, AND JUDICIAL ACTIONS
Executive order №. 12083

established the Energy Coordinating Committee, composed of Secretaries of Energy (Chairman), State, Treasury, Defense, and others to coordinate energy policy and management. The Committee replaced the Energy Resources Council established October 8, 1974. 
1978

November 9

1979

January 16
UNITED STATES AND WORLD EVENTS
PRESIDENTIAL, LEGISLATIVE, AND JUDICIAL ACTIONS

National Energy Act, consisted of five major acts: National Energy Conservation Policy Act, established the weatherization grant program, loan insurance for solar systems, conservation programs for local govermment public buildings, energy standards for consumer products, and provided funds for numerous energy technologies; Powerplant and Industrial Fuel Use Act, established the fuel conversion program to facilitate utility powerplant conversion to coal; Public Utilities

Regulatory Policy Act, set standards for electric utilities and oil and natural gas transportation systems; Energy Tax Act, authorized residential energy credits, gas guzzler tax, incentives for van pooling, and adjusted investment credits for new energy technologies; Natural Gas Policy Act, set and adjusted price controls on natural gas.

\section{AGENCY ACTIONS}


1979

UNITED STATES AND WORID EVENTS
PRESIDENTIAL, LEGISIATIVE, AND JUDICIAL ACTIONS

AGENCY ACTIONS

March 28 Three Mile Island power plant near Harrisburg, Pennsylvania became one of the most severe and widely publicized nuclear accidents to occur.

Spring

Gasoline shortages developed in several areas of the country, resulting in consumer gas lines.

May 27

June 3

Ixtoc I oil well in the southern Gulf of Mexico blew out and released 600,000 tons of crude oil, the largest oil spill on record.

August 17

August 24

Septenber 29
President Carter began program to gradually lift price controls on damestic crude oil. and asked Congress to approve tax on oil companies for the "windfall" profits.
National Energy Plan II released by Department of Energy.
Charles W. Duncan, Jr., named second Secretary of Energy.

Export Administration Act, prohibited export of Alaskan oil to Japan. 
November 3 Revolutionaries in Tehran, Iran, seized U.S. embassy and took 90 people hostage, including 63 Americans. On November 12 President Carter suspended all Iranian oil imports, and on November 14 froze all Iranian 1980 assets in American banks.

February 12

April 2
Executive Order №. 12192 setup the State Planning Council (SPC) to advise the Executive branch and work with Congress in making and implementing decisions on nuclear waste management and disposal. The Council was created for 18 months and ended activity on August 12, 1981.

Crude Oil Windfall Profit Tax Act, and Title III of the act, Home Energy Assistance Act, established tax on crude oil and granted money to states for energy cost assistance to low income people. 
UNITED STATES AND WORID EVENTS

$\underline{1980}$

June 30

August 3
PRESIDENTIAL, LEGISLATIVE, AND JUDICIAL ACTIONS

Energy Security Act, consisted of six major acts: U.S. Synthetic Fuels Corporation Act, created new corporation to help finance research and development of synthetic fuels and set production goals; Bicmass Energy and Alcohol Fuels Act, established demonstration projects in Department of Agriculture, and office of Alcohol Fuels in Department. of Energy; Renewable Energy Resources Act, established incentives and goals for waste renewable programs; Solar Energy and Energy Conservation Act and Solar Energy and Energy Conservation Bank Act, established fund in Department of Housing and Urban Development to provide assistance for solar development; Geothermal Energy Act, funded the Geothermal Resources Development Fund established in 1974 to make loans for geothermal projects.

Ocean Thermal Energy Conversion Act, authorized and allowed work to begin on conversion plants, subject to National Oceanic and Atmospheric Administration approval. 
1980

September 8

octaber 1

October 7

November 4 Ronald Reagan elected President.

December 11
PRESIDENITIAL, LEGISLATIVE, AND JUDICIAL ACTIONS

Wind Energy Systems Act, accelerated wind development programs in Department of Energy.

West Valley Demonstration Project Act, authorized assumption of responsibility for the Western New York Nuclear Fuels Service Center, West Valley, New York, by the Department of Energy.

Magnetic Fusion Engineering Act, accelerated research and development on magnetic fusion energy technologies with goal of construction and successful operation of a demonstration plant by the year 2000 .

Comprehensive Environmental Response, Liability and Compensation Act, established "superfund" to clean up hazardous waste dumps. 
$\underline{1980}$

December 22

December 22

December 22

$\underline{1981}$

January 20

Fifty-three American hostages

were released by Iran on

Inauguration Day after 444

days of captivity.
PRESIDENTIAL， IEGISIATIVE， AND JUDICIAL ACTIONS

Low-Level Waste Policy Act, established a policy that each state must provide facilities to the nuclear industry for disposal of low level radioactive waste. The Act allowed the formation of state compacts, or for states to join together and build facilities serving those states.

Nuclear Safety Research, Development and Demonstration Act, established in Department of Energy a program to improve safety of nuclear power plants.

Alaska Federal-Civilian Energy Efficiency Swap Act, allowed U.S. Government installations in Alaska to buy power from nonfederal generating facilities.

January 23

James B. Edwards named third Secretary of Energy. 


\section{UNITED STATES AND} WORLD EVENTS

1981

January 28

February 18

President Reagan presented "America's New Beginning: A Program for Economic Recovery" to the Congress.

February 25

March 30

July

President Reagan and three others wounded in assassination attempt.

E. I. duPont de Nemours and Co.

\section{PRESIDENTIAL, LEGISLATIVE,} AND JUDICIAL ACTIONS

Executive Order No. 12287

decontrolled prices on crude oil and refined petroleum products.

Secretary Edwards announced major reorganization of Department of Energy, and also created an Energy Policy Task Force. announced takeover of Conoco

Oil Co., largest merger in U.S. history.

The third national energy plan, "Securing America's Energy

Future," released by Department of Energy. 


\section{$\underline{1981}$}

September 9

Octaber 8

Senate ratified Protocol I, of Tlatelolco Treaty; the U.S. cannot deploy, store, or use nuclear weapons in Puerto Rico, U.S. Virgin Islands, or Guantanamo Naval Base.

\section{November 13}

PRESIDENTIAL, IEGISLATIVE, AND JUDICIAL ACTIONS

Executive Order №. 12319 terminated the six river basin commissions established to carry out the Water Resources Planning Act of 1962.

Reagan Administration announced nuclear energy policy; proposed accelerated deployment of methods for storing high-level radioactive waste; and lifted ban on conmercial reprocessing of nuclear fuel.

$\underline{1982}$

May 24

President Reagan proposed legislation transferring most responsibilities of Department of Energy to Department of Commerce. 


\section{APPENDIX ONE}

\section{PRESIDENTIAL ACTIONS RELATED TO ENERGY}

1945

September 28 Proclamation No. 2667 reserved offshore oil rights for the U.S. Government.

$\underline{1946}$

July 16 Reorganization Plan No. 3 created the Bureau of Land Management in the Department of Interior.

$\underline{1950}$

January 3 Water Resources Policy Cammission (the Cooke Camission) established in the Executive Office of the President. Final report issued Decenber 1, 1950.

$\underline{1951}$

January

President's Materials Policy Commission (the Paley Commission), established. "Resources for Freedam," final report issued June 1952, forecast electric power and fuel demands.

$\underline{1953}$

January 20 Executive Order No. 10426 set aside submerged lands on the continental shelf as a naval petroleum reserve under authority of the Secretary of Navy.

December 8 President Eisenhower delivered "Atans for Peace" speech before the United Nations.

1954

June

President Eisenhower authorized a cabinet rank Advisory Committee on Energy Supplies and Resources Policy, chaired by the Director of the Office of Defense Mobilization. Report released on February 26, 1955. 
February 17 Natural Gas Bill vetoed by President Eisenhower. The bill would have provided independent producers of natural gas exemption from control by the Federal Power Camission.

August 24 Middle East Emergency Camittee established in the Executive Office of the President to help alleviate oil shortages in Western Europe.

1957

June 26 President Eisenhower appointed a Special Comittee to Investigate Crude Oil Imports. The Special Committee's report submitted on July 29, 1957.

November President's Science Advisory Committee created by transfer of the Science Advisory Committee of the Office of Defense Mobilization to the Executive Office of the President.

$\underline{1958}$

May 26

June 23

President Eisenhower dedicated Shippingport Atomic Power Station.

1959

President Eisenhower sent to Congress a proposed international agreement with the European Atomic Energy Community (Euratom) for joint development of U.S. type power reactors to provide six nations with installed capacity of one million kilowatts by 1963.

March 10 Proclamation No. 3279 established Mandatory Oil Import Program, to limit low price imported oil and stimulate development of domestic production and refining capacity through quotas.

August 14 Executive Order No. 10831 established the Federal Radiation Council.

$\underline{1961}$

September 5 President Kennedy ordered resumption of underground nuclear testing following atmospheric nuclear tests by the Soviet Union.

December 2 The Petroleum Study Comittee, established by President Kennedy, instructed the director, office of Emergency Planning to lead a study of petroleum requirements in relation to national security. Report issued on September 4, 1962. 
March 17 President Kennedy asked Atamic Energy Commission Chaiman Glenn T. Seaborg to report on the role of nuclear power in the econamy. The Chaiman submitted the report on November $20,1962$.

April 24 President Kennedy authorized U.S. resumption of atmospheric nuclear testing.

June 8 President Kennedy created the Office of Science and Technology in the Executive Office of the President.

\section{$\underline{1963}$}

February 15 An Interdepartmental Energy Study Group, chaired by the Director, office of Science and Technology, directed a comprehensive study of energy resources. The report completed June 1964.

August 5 The Limited Nuclear Test Ban Treaty, signed by the United States, Great Britain, and Soviet Union, banned nuclear tests in the oceans, atmosphere, and outer space. The Treaty took effect in November 1963.

\section{$\underline{1964}$}

June 24 A Cabinet Cormittee on Appalachian Coal established by President Johnson.

\section{$\underline{1967}$}

November 25 An Energy Policy Staff established in the Office of Science and Technology.

\section{9}

February 20 A Cabinet Task Force on Oil Import Control established to review the mandatory oil import program. Submitted a report to President Nixon on February 2, 1970. 
January 29 Presiderit Nixon appointed Russell E. Train, then Under Secretary of Interior, as Chairman of the Council on Environmental Quality. The other members were Robert Cahn and Gordon J.F. MacDonald. The Council submitted it's first annual report to Congress in August 1970.

February 20 An Oil Policy Committee established under direction of General Lincoln, head of the office of Emergency Preparedness.

February 5 Executive Order 11507, "Prevention, Control and Abatement of Air and Water Pollution," established guidelines for control of pollution from federal facilities and projects.

March 5 Executive Order No. 11514 reinforced the National Environmental Policy Act; ordered federal agencles to monitor and evaluate activities for the protection of the environment, and gave additional broad powers to the Council on Environmental Quality.

July 9 President Nixon sent to Congress Reorganization Plan No. 3, which created the Environmental Protection Agency from components of Departments of Interior; Health, Education and Welfare; Agriculture; and the Atomic Energy Commission. The Plan abolished Federal Water Quality Administration (Interior) and Federal Radiation Council (HEW) .

July 9

President Nixon sent to Congress Reorganization Plan No. 4, which established as of October 2, 1970, the National Oceanic and Atmospheric Administration in the Department of Commerce.

August 6

The Domestic Council established an Energy Subcommittee.

September General Lincoln of the Office of Emergency Preparedness, set up a Joint Board on Fuel Supply and Transportation.

$\underline{1971}$

June 4 In his first message to Congress on energy policy, President Nixon proposed a new Department of Natural Resources, consolidating all federal energy resource and development programs. 
President Nixon appointed a Counsellor to the President for Natural Resources, to coordinate domestic natural resources, environment, and energy matters.

February 7 Executive Reorganization Plan No. 1 abolished the Office of Emergency Preparedness and the Office of Science and Technology (OST). The OST's functions were transferred to the National Science Foundation. The Plan also transferred the oil import program to the office of Deputy Secretary of Treasury William Simon. The reorganization plan went into effect on July 1 , 1973.

April 18 Executive Order No. 11712 established National Energy Office in the Executive Office of the President and a Special Committee on Energy, camposed of the Advisor to the President for National Security (Henry Kissinger), Domestic Affairs Advisor (John Ehrlichman) and Secretary of the Treasury (George Shultz).

The Executive Order also ended the oil import quota system and substituted an import fee of 1 cent per gallon of crude oil.

President Nixon directed that a new post of Assistant Secretary for Energy and Minerals be created in the Department of Interior, and an Office of Energy Conservation.

June 29 Executive Order No. 11726 combined the Special Energy Committee and National Energy Office in an expanded Energy Policy Office within the Executive Office of the President to formulate and coordinate energy policy at the presidential level. Former Governor Love of

Colorado named head of the Office and Assistant to the President. Love resigned on December 3, 1973.

President Nixon proposed creation of an Energy Research and Development Administration. The new agency would include all functions of the Atomic Energy Commission except licensing and regulatory responsibilities, which would be placed under a separate Nuclear Energy Cormission.

President Nixon again proposed a new Department of Energy and Natural Resources. 
October 11 President Nixon established an Energy Research and Development Advisory Council, composed of leading experts in various areas of energy research outside government, to report to the Energy Policy Office.

November 7 President Nixon gave first address to the Nation since oil embargo, and called for Project Independence (self-sufficiency from foreign supplied petroleum by 1980), a return to daylight savings time, and the passage of previously proposed legislation.

November 12 An Energy Emergency Action Group, headed by chief energy advisor John Love, established.

November 25 President Nixon after an address to the Nation on energy, announced several actions under authority of the Economic Stabilization Act of 1970 and the Defense Production Act of 1950. Included were new allocation programs for middle distillates, gasoline, and jet fuels, and regulations for halting power plants and industries switching fram coal to oil.

December 4 Executive Order No. 11748 established the Federal Energy Office in the Executive Office of the President. William Simon named Executive Director of the Energy Energency Action Group. President Nixon assumed chairmanship of the Group.

$\underline{1974}$

March 6 National Energy Emergency Act vetoed by President Nixon.

October 8 Executive Order No. 11814 established the Energy Resources Board, later called Energy Resources Council, to be headed by Rogers Morton, with Frank Zarb as Executive Director.

1975

May 20

The Surface Mining Control and Reclamation Act vetoed by President Ford.

July 21

The Petroleum Price Review Act vetoed by President Ford.

September 9 President Ford vetoed legislation extending domestic oil price controls for additional six months. 

tuel tron clvilian reactors, and delay the construction of the Clinch River Breeder Reactor.

April 29 President Carter submutted to Congress National Energy Plan I, and called for a new, consolidated cabinet level Department of Energy.

1978

September 27 Executive Order No. 12083 established the Energy Coordinating Commuttee, composed of Secretarles of Energy (Chalman), State, Treasury, Defense and others to coordinate energy policy and management. The cormuttee replaced the Energy Resources Council established October 8, 1974.

$\underline{1979}$

August 17 President Carter began program to gradually lift price controls on domestic crude oll, and asked Congress to approve tax on oll companies for the "windfall" profits.

$\underline{1980}$

February 12 Lxecutive Order INo. 12192 stt up the State Planning Council (SPC) to advise the Executive branch and work with Congress in making and implementing decisions on nuclear waste management and disposal. The Council was created for 18 months and ended activity on August 12, 1981.

1981

Januar: 28 Lxecutive Order No. 12287 decontrolled prices on crude 011 and retıned petroleum products.

Septenbur 9 Executive Order No. 12319 termunated the six river basin commissions established to carry out the water Resources Planning Act of 1962. 
1981

october \&

Reugan Actrilistraticn announced nuclear energy policy; proposed accelerated deployment of m trouls for storing high-level radioactive waste; and lifted ban on camercial reprocessing of nuclear iuel.

1982

Hay 24

Iresident keagan propusedi legislation transferring most responsibilities of Department of Energy to Department of Conmerce. 


\section{APPENDIX TWO}

\section{ENEFGY REIATED LEGISLATION}

\section{$\underline{1946}$}

May 13

August 1

$\underline{1947}$

July 26

$\underline{1948}$

June 29

June 30

$\underline{1950}$

May 10

September 8

National Sclence Foundation Act, established the Nationd Science Foundatiun.

National Security Act, unified all branches of the armed services in a Departriknt of Deferise. The act also established the National Security Resources Board as an incependent agency. In June 1949 the Board was transferred to the Executive Office of the President. During the Korean Conflict, the head of the Office of Defense Mobilization assunied all functions.

Federal-Ald Highway Act, a series of amendments to the 1920 act, authorlzed cippropriations for continued construction of highways.

Water Pollution Control Act, directed the Public Health Service of the Federal Security Agency and the Federal Works Agency to study pollution problens. The act also established a water Pollution Control Advisory Board.

Defense Production Act, gave broad powers to the President and executive branch, including establishment of agencies to oversee production and distribution of energy products and resources during periods of emergency, such as the mobllization for the Korean conflict, and 1973-74 o1l embargo.

U.S. DEPARTMENT OF ENERGY/HISTORY DIVISION 
$\underline{1953}$

Nay 22

Submerged Lands Act, gave states clear title to all lands within 3 miles of the Atlantic and Pacific coasts and 10.5 miles of the Gulf Coast. The act was supported by the new Eisenhower Administration and overruled the decision of U.S. v. California (1947) and 'Truman's Executive Order of January 20, 1953.

August 7 Outer Continental Shelf Act, gave the Federal Government jurisdiction over the ocean floor beyond the 3 mile boundary.

$\underline{1954}$

August 13

Multiple Mineral Development Act, allowed for multıple use of public lands.

August 30

Atomic Energy Act of 1954, major revision of the 1946 Act gave added erphasis to development of peacetime uses of atomic energy, and encouraged private and public groups to build, own, and operate power reactors.

1955

June 21

Trade Agreements Extension Act, section 7, authorized the Director ot the Otfice of Defense Mobilization to be responsible for advising the President when dependence upon umports of any "articles" impaired national security.

August 4 Atomic Energy Community Act, authorized local self-govemment, the transfer of municipal functions and sale of property at Richland, Washington, and Oak Rlage, Tennessee.

1956

April 11 Colorado River Storage Project Act, authorızed construction of multıpurpose water resource development projects. 
June 29 National System of Interstate and Defense Highways Act, authorized a 13 year program of 1957 highway construction to be financed by various taxes.

September 2 Price-Anderson Act, provided financial protection to the public, Atomic Energy Camission licensees and contractors in the event of a major nuclear power plant accident.

1958

July 29

National Aeronautics and Space Act, established National Aeronautics and Space Administration to conduct civilian aeronautical and space research.

August 23 Federal Aviation Act, established the Federal Aviation Authority to regulate air transportation.

1960

July 7

Coal Research Act, established the Office of Coal Research in the Department of Interior.

$\underline{1961}$

August

Senate Comittee on Interior and Insular Affairs established The National Fuels and Energy Study Group which completed its report on September 7, 1962.

1962

October 11 Trade Expansion Act, authorized the President to impose mandatory oil import quotas.

$\underline{1963}$

December 17 Clean Air Act, provided assistance to states and local governments to research air pollution problems. Major amendments were made to the act in 1970. 
August 26 Private Ownership of Special Nuclear Materials Act, allowed the power industry to own fuel for power reactors. After June 30, 1973 private ownership of power reactor fuels would became mandatory.

September 3 Wilderness Act, established the National Wilderness Preservation System, which would ultimately prohibit mining activity on designated lands.

1965

October 2 Water Quality Act, established the Federal Water Pollution Control Administration in the Department of Health, Education and Welfare.

October 20 Solid Waste Disposal Act, provided assistance to public and private agencies for study, collection and disposal of solid waste.

1966

September Federal Metal and Non Metallic Mine Safety Act, gave Department of Interior, Bureau of Mines, regulatory authority over health and safety of mines, including uranium mines.

October 15 Department of Transportation Act, established the Department of Transportation and gave DOT responsibility for pipeline safety standard setting and enforcement. The act also

1967 transferred Interstate Commerce Commission authority over surface transport of fuels to DOT.

November 21 Air Quality Act, strengthened the Clean Air Act of 1963 with additional funding. Title II of the Air Quality Act, the National Emission Standards Act, gave authority to the Secretary of Health, Education and Welfare to set auto emission standards.

$\underline{1968}$

August 12 Natural Gas Pipeline Safety Act, set standards for pipeline safety.

September 30 Colorado River Basin Project Act, authorized the Secretary of Interior to conduct studies on future development of the colorado River Basin and construction of some water development projects. 
January 1 National Environmental Policy Act, established the Council on Environmental Quality.

December 30 Federal Coal Mine Health and Safety Act, instituted new regulatory powers for standards and inspection, and new federal responsibility for determining workmen's campensation pertaining to black lung disease.

December 30 Tax Reform Act, reduced the depletion allowance on oil fram $27 \frac{1}{2}$ percent to 22 percent.

April 3

Water Ouality Improvement Act, and title II of the Act, the Environmental Quality Imorovement Act, authorized an Office of Environmental Quality in the Executive Office of the President, to provide professional and administrative support to the council on Environmental Quality, and instituted new measures to control wastes, particularly oil, from entering bodies of water.

October 21 Merchant Marine Act Amendment, allowed the federal government to provide subsidies to finance construction of oil tankers and liquid natural gas transport vessels.

October 26

Resource Recovery Act, amended the Solid Waste Disposal Act and provided financial assistance to states and local governments to construct disposal facilities.

December 24 Geothermal Steam Act, authorized issuance of leases for development of geothermal steam.

December 31 Clean Air Amendments, set numerous emission standards, including those for autamobiles.

$\underline{1973}$

April $30 \quad$ Economic Stabilization Act Amendments, authorized fuel allocations.

November 27 Emergency Petroleum Allocation Act, provided authority for a mandatory oil allocation program run by the Energy Policy Office.

December 15 Emergency Daylight Saving Time Energy Conservation Act, required a return to daylight saving time through April 1975.

U.S. DEPARIMENT OF ENERGY/HISTORY DIVISION 
May 7

June 22

September 3 Geothermal Energy Research, Development, and Demonstration Act, authorized the Geothermal Energy Joordination and Management Project, including members from National Aeronautics and Space Administration, Atamic Energy Commission, and National Science Foundation. Activities of project transferred to Energy Research and Development Administration. The act also established the Geothermal Resources Development Fund.

September 3 Solar Heating and Cooling Demonstration Act, authori sed National Aeronautics and Space Adninistration to conduct research, development and manufacture of solar heating and cooling equipment with assistance from Department of Housing and Urban Development.

October 5 Daylight Saving Time Energy Conservation Act Repeal, from the last Sunday in October 1974 through the last Sunday in April 1975.

October 11 Energy Reorganization Act, abolished the Atomic Energy Commission and created the Energy Research and Development Administration and Nuclear Regulatory Commission.

October 26 Solar Energy Research, Develogment, and Demonstration Act, authorized the Solar Energy Coordination and Management Project, including members from National Science Foundation, Department of Housing and Urban Development, Federal Power Commission, and National Aeronautics and Space Administration to coordinate research in solar energy. Activities of project transferred to Energy Research and Development Administration. The act also authorized establishment of the Solar Energy Research Institute. 
December 5 Extension of Emergency Petroleum Allocation Act of 1973 until August 31, 1975.

December 31 Federal Non-Nuclear Energy Research and Develogment Act, required the administrator of the Energy Research and Development Administration to submit to Congress annually a comprehensive plan for energy research, development, and demonstration.

1975

January 4 Federal-Aid Highway Act, established the $55 \mathrm{mph}$ speed limit.

September 29 The Emergency Petroleum Allocation Act, which expired on August 31, was extended until November 15.

December 22 Energy Policy and Conservation Act, established the Strategic Petroleum Reserve.

$\underline{1976}$

April 5 Naval Petroleum Reserves Production Act, authorized Department of Interior to establish national petroleum reserves and prepare plans for future production of existing naval reserves. The act also authorized exploration of Petroleum Reserve No. 4 in Alaska.

August 14 Energy Conservation and Production Act, authorized continuation of the Federal Energy Administration and provided incentives for domestic energy production.

August 14 Energy Conservation and Standards for New Buildings Act, established energy conservation $\underline{1977}$

February 2 Emergency Natural Gas Act, provided special allocation programs to aid in the supply emergency.

August 3 Surface Mining Control and Reclamation Act, regulated surface coal mining operations and established the Office of Surface Mining Reclamation and Enforcement in the Department of Interior. 
August 4 Department of Energy Act, abolished Energy Research and Development Administration, Federal Energy Administration and transferred their functions to new Department of Energy.

$\underline{1978}$

March 10 Nuclear Non-Proliferation Act, authorized the President to pursue international studies on proliferation of nuclear materials and encouraged nations to sign Treaty on the Non-Proliferation of Nuclear Weapons.

November 9 National Energy Act, consisted of five major acts: National Energy Conservation Policy Act, established the weatherization grant program, loan insurance for solar systems, conservation programs for local government public bujldings, energy standards for consumer products, and provided funds for numerous energy technologies; Powerplant and Industrial Fuel Use Act, established the fuel conversion program to facilitate utility powerplant conversion to coal; Public Utilities Regulatory Policy Act, set standards for electric utilities and oil and natural gas transportation systems; Energy Tax Act, authorized residential energy credits, gas guzzler tax, incentives for van pooling, and adjusted investment credits for new energy technologies; Natural Gas Policy Act, set and adjusted price controls on natural gas.

September 29 Export Administration Act, prohibited export of Alaskan oil to Japan.

1980

April 2 Crude Oil Windfall Profit Tax Act, and Title III of the act, Home Energy Assistance Act, established tax on crude oil and granted money to states for energy cost assistance to low income people. 
$\underline{1980}$

June 30 Energy Security Act, consisted of six major acts: U.S. Synthetic Fuels Corporation Act, created new corporation to help finance research and development of synthetic fuels and set production goals; Biomass Energy and Alcohol Fuels Act, established demonstration projects in Department of Agriculture, and Office of Alcohol Fuels in Department of Energy; Renewable Energy Resources Act, established incentives and goals for waste renewable programs; Solar Energy and Energy Conservation Act and Solar Energy Conservation Bank Act, established fund in Department of Housing and Urban Development to provide assistance for solar development; Geothermal Energy Act, funded the Geothermal Resources Development Fund established in 1974 to make loans for geothermal projects.

August 3 Ocean Thermal Energy Conversion Act, authorized and allowed work to begin on conversion plants, subject to National Oceanic and Atmospheric Administration approval.

September 8 Wind Energy Systems Act, accelerated wind development programs in Department of Energy.

October 1 West Valley Demonstration Project Act, authorized assumption of responsibility for the Western New York Nuclear Fuels Service Center, West Valley, New York, by the Department of Energy.

October 7 Magnetic Fusion Engineering Act, accelerated research and development on magnetic fusion energy technologies with goal of construction and successful operation of a demonstration plant by the year 2000 .

December 11 Comprehensive Environmental Response, Liability and Compensation Act, established "superfund" to clean up hazardous waste durms.

December 22 Low-Level Waste Policy Act, established a policy that each state must provide facilities to the nuclear industry for disposal of low level radioactive waste. The Act allowed the formation of state compacts, or for states to join together and build facilities serving those states. 
December 22 Nuclear Safety Research, Development and Demonstration Act, established in Department of Energy a program to improve safety of nuclear power plants.

December 22 Alaska Federal-Civilian Energy Efficiency Swap Act, allowed U.S. Government installations in Alaska to buy power fram non-federal generating facilities. 
1947

June 16

June 23

$\underline{1954}$

March 15

Alabama v. Texas

Supreme Court upheld constitutionality of Submerged Lands Act of 1953.

June 7

Phillips v. Wisconsin

Supreme Court declared the Federal Power Commission had authority to set prices for natural gas including wholesales of natural gas.

1965

December 29 Scenic Hudson Preservation Conference v. Federal Power Cormission U.S. Court of Appeals for the Second Circuit ruled that the Federal Power Comission was a public body and therefore must vigorously advance the public's interest.

$\underline{1971}$

July 23

Calvert Cliffs Coordinating Comittee v. Atomic Energy Camission D.C. Court of Appeals ruled that Atomic Energy Comission regulations did not comply with National Environmental Policy Act of 1969, and obligated the Commission to incorporate wider environmental concerns in its regulatory program and licensing procedures. 
January 13 Natural Resources Defense Council v. Morton

D.C. Court of Appeals prohibited a Department of Interior sale of leases to 300,000 acres on the outer continental shelf. Environmental groups charged the govermment's environmental irmact statement for the sale was inadequate because it did not mention alternative sources of oil to prevent the danger of oil spills.

April 3 Northern States Power Company v. Minnesota

Supreme Court granted the Federal Government preemption over the states to regulate radiation control standards for nuclear power plants.

$\underline{1975}$

March 17 United States v. Maine

Supreme Court ruled states do not have jurisdiction over and possession of the entire outer continental shelf. 
FEDERAL ENERGY OFFICIAIS

(By agency in alphabetical order)

ATOMIC ENERGY COMMISSION

Conmissioners

Sumner T. Pike

David E. Lilienthal, Chairman

Robert F. Bacher

William W. Waymack

Lewis L. Strauss

Chairman

Gordon Dean

Chairman

Henry DeWolf Smyth

Thomas E. Murray

Thomas Keith Glennan

Eugene M. Zuckert

Joseph Campbell

willard F. Libby

\section{Term of Office}

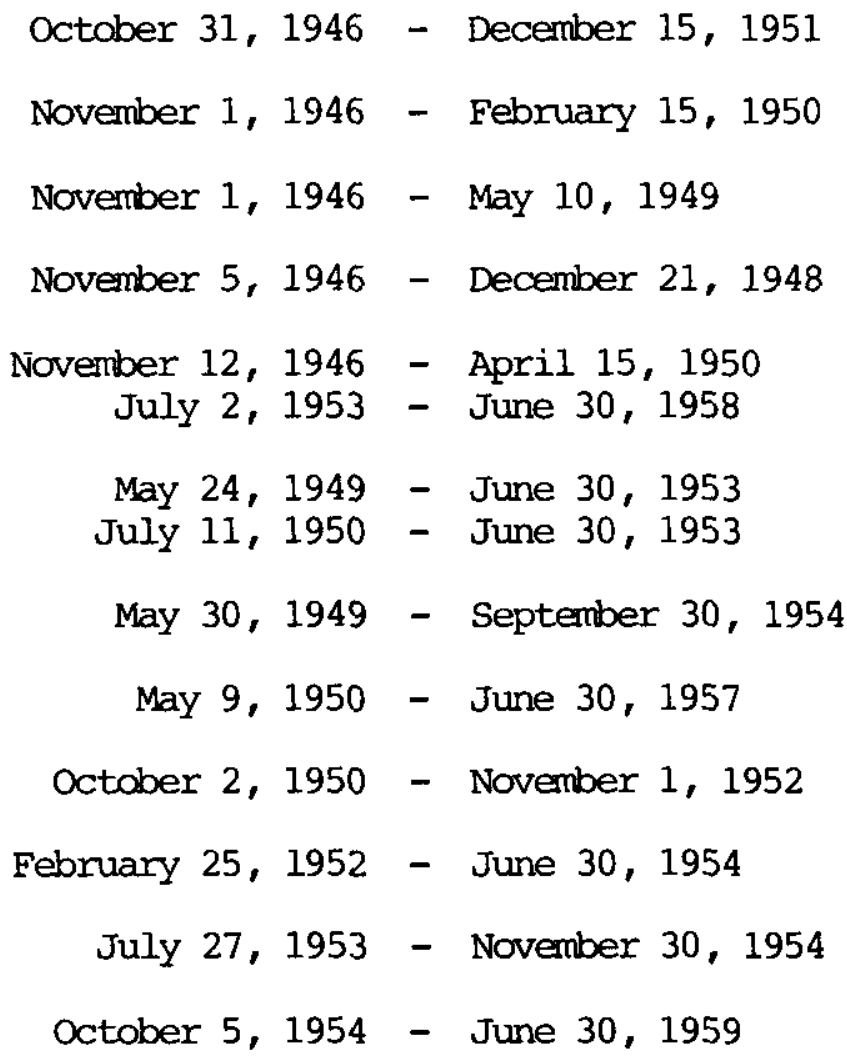


ATOMIC ENERGY COMMISSION (Cont.)

John Von Neumann

Harold S. Vance

John S. Graham

John Forrest Floberg

John A. Mocone, Chaimman

John H. Williams

Robert E. Wilson

Loren K. Olson

Glen T. Seaborg, Chairman

Leland J. Haworth

John G. Palfrey

James T. Ramey

Gerald F. Tape

Mary I. Bunting

Wilfred E. Johnson

Samue1 M. Nabrit

Francesco Costagliola

Theos J. Thompson
March 15, 1955 - February 8, 1957

October 31, 1955 - August 31, 1959

September 12, 1957 - June 30, 1962

October 1, 1957 - June 23, 1960

July 14, 1958 - January 20, 1961

August 13, 1959 - June 30, 1960

March 22, 1960 - January 31, 1964

June 23, 1960 - June 30, 1962

March 1, 1961 - August 16, 1971

April 17, 1961 - June 30, 1963

August 31, 1962 - June 30, 1966

August 31, 1962 - June 30, 1973

July 15, 1963 - April 30, 1969

June 29, 1964 - June 30, 1965

August 1, 1966 - June 30, 1972

August 1, 1966 - August 1, 1967

October 1, 1968 - June 30, 1969

June 12, 1969 - Noveriber 25, 1970 
ATOMIC ENERGY COMMISSION (CONt.)

Clarence E. Larson

James R. Schlesinger, Chairman

William O, Doub

Dixy lee Ray

Chairman

William E. Kriegsman

William A. Anders

\section{Secretaries}

James R. Schlesinger

Charles w. Duncan, Jr.

James B. Edwards

\section{Deputy Secretaries}

John F. O'Leary

John C. Sawhill

Lymn Coleman

William Kenneth Davis

$$
\begin{array}{r}
\text { September 2, } 1969 \text { - June 30,1974 } \\
\text { August 17, } 1971 \text { - January 26, } 1973 \\
\text { August 17, } 1971 \text { - August 17, } 1974 \\
\text { August 8, } 1972 \text { - January 18, } 1975 \\
\text { February 6, } 1973 \text { - } \\
\text { June 12, } 1973 \text { - December 31, } 1974 \\
\text { August 6, } 1973 \text { - January 18, } 1975
\end{array}
$$

DEPARIMENT OF ENERGY

Term of office

August 4, 1977 - August 23, 1979

August 24, 1979 '- January 20, 1981

January 23, 1981 - Present

\section{Term of Office}

October 21, 1977 - September 30, 1979

October 4, 1979 - October 8, 1980

December 23, 1980 - January 20, 1981

May 14, 1981 - Present 
DEPARTMENT OF ENERGY (Cont.)

Under Secretaries

Dale D. Myers

John Deutsch

Guy W. Fiske

Administrators

Robert C. Seamans

Robert w. Fri (Acting)

Deputy Administrator

Robert W. Fri

\section{Administrators}

John Sawhill

Frank Zarb

Gorman Smith (Acting)

John O'Leary
Term of Office

$$
\begin{array}{r}
\text { October 21, } 1977 \text { - May 31, } 1979 \\
\text { August 8, } 1979 \text { - April 1, } 1980 \\
\text { October 5, } 1981 \text { - May 1, } 1982
\end{array}
$$

ENERGY RESEARCH AND DEVELOPMENT ADMINISTRATION

Term of Office

December 1974 - January 1977
January 1977 - September 1977
Term of Office

March 1975 - September 1977

FEDERAL ENERGY ADMINISTRATION

Term of Office
April 17, 1974 - December 1974
Decenber 18, 1974 - January 15, 1977
January 15, 1977 - February 3,1977
February 5, 1977 - September 30, 1977


FEDERAC ENERGY ADMINISTRATION (Cont.)

Deputy Administrators

Eric Zausner (Designated Acting)

John Hill

David Bardin

Gorman Smith (Acting)

Administrator

william simon

Deputy Administrator

John Sawhill

Camissioners

Claude L. Draper

Basil Manly

Chairman

\section{Term of Office}

Early 1974 - July 31, 1976 Decenber 18, 1974 - July 31, 1976

Early 1975 - July, 1976

May 1977 - September 30, 1977

February 1977 - June 1977

FEDERAL ENERGY OFFICE

\section{Term of Office}

Decenber 4, 1973 - April 17, 1974

Term of Office

December 4, 1973 - April 17, 1974

FEDERAL ENERGY REGULATORY COMISSION

Formerly

FEDERAL POWER COMMISSION

$1945-1977$

\section{Term of office}

December 23, 1930 - June 22, 1956

June 22, 1933 - October 1, 1945

September 21, 1944 - September 14, 1945 
FEDERAL ENERGY REGULATORY COMMISSION (Cont.)

John w. Scott

Leland Olds

Chairman

Nelson Lee Smith

Chairman

Harrington Wimberly

Richard Sachse

Thomas C. Buchanan

Chairman

Mon C. Wallgren

Chairman

Dale E. Doty

Jerome K. Kuykendall

Chairman

Seaborn L. Digby

Frederick Stueck

William R. Connole

Arthur Kline

John B. Hussey
June 24, 1937 - June 15, 1945

July 7, 1939 - June 22, 1949

Decermber 14, 1945 - January 1, 1947

October 26, 1943 - June 22, 1955

January 1, 1947 - May 24, 1950

October 5, 1945 - June 22, 1953

November 1, 1945 - June 22, 1947

June 14, 1948 - May 15, 1953

January 5, 1952 - June 22, 1952

July 8, 1952 - May 15, 1953

October 18, 1949 - October 1, 1951

May 24, 1950 - October 1, 1951

May 22, 1952 - June 22, 1954

May 15, 1953 - January 1, 1962

May 15, 1953 - June 22, 1957

August 17, 1957 - August 31, 1961

August 17, 1953 - June 22, 1958

July 9, 1954 - July 15, 1961

June 23, 1955 - June 22, 1960

June 23, 1956 - August 13, 1961

June 23, 1958 - March 17, 1960 


\section{FEDERAL ENERGY REGULATORY COMMISSION (Cont.)}

Paul A. Sweeney

Joseph C. Swidler

Chainman

Howard Morgan

Lawrence J. O'Connor, Jr.

Charles R. Ross

Harold C. Woodward

David S. Black

Carl E. Bagge

Lee C. White, Chairman

John A. Carver, Jr.

Albert Bush Brooke, Jr.

John N. Nassikas, Chairman

Pinkney Walker

Rush Moody, Jr.

William L. Springer

Don S. Smith

John H. Holloman

U.S. DEPARTMENT OF ENERGY/HISTORY DIVISION

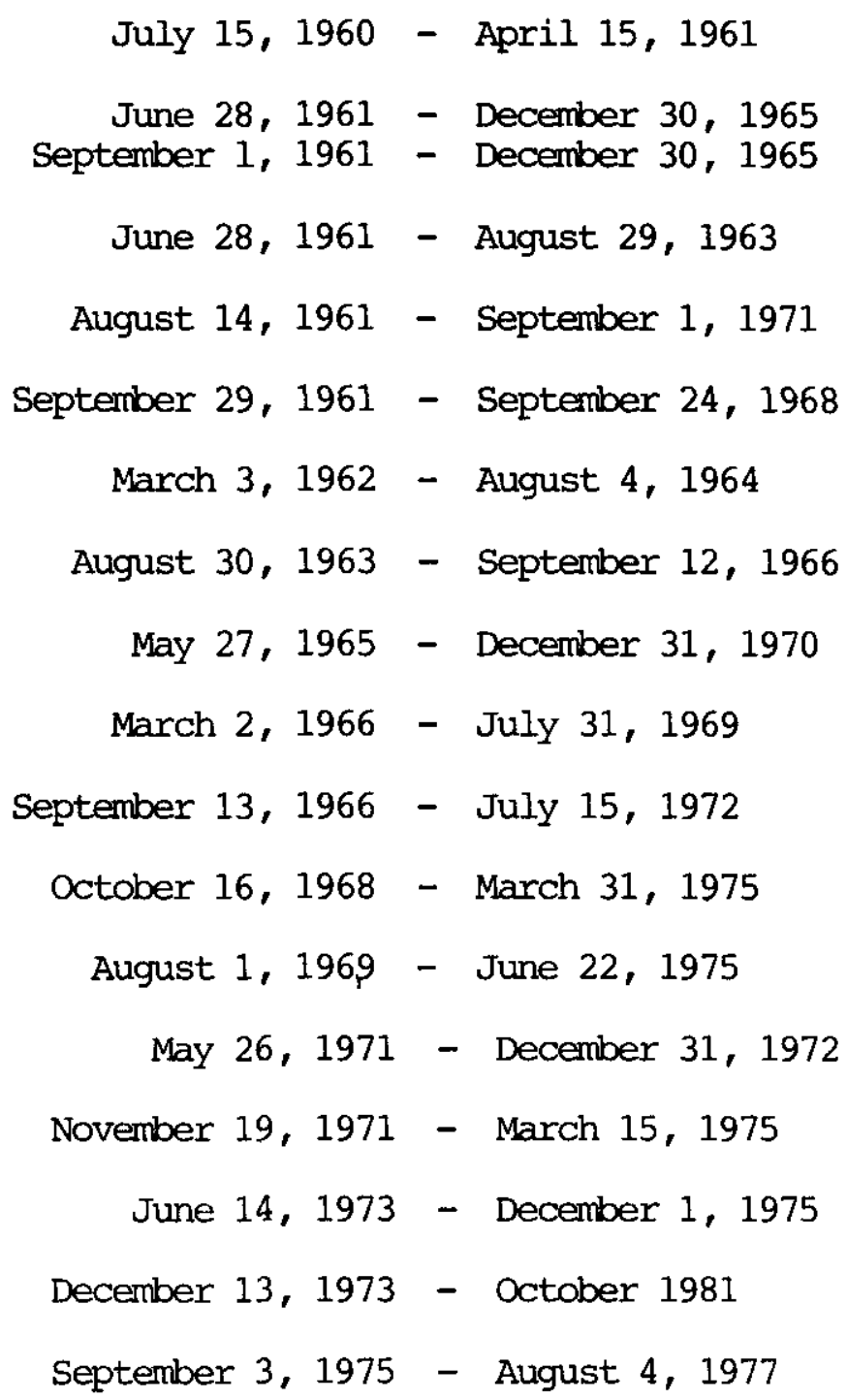


FEDERAL ENERGY REGULATORY COMMISSION (Cont.)

Richard L. Dunharn

James G. Watt

Charles B. Curtis, Chasman

Georgiana Sheldon

George R. Hall

Matthew Holdon, Jr.

Charles M. Butler, Chairman

David Hughes

Anthony G. Sousa

\section{$\underline{\text { Secretaries }}$}

Julius Krug

Oscar Chapman

Douglas McKay

Frank Seaton

Stewart L. Udall

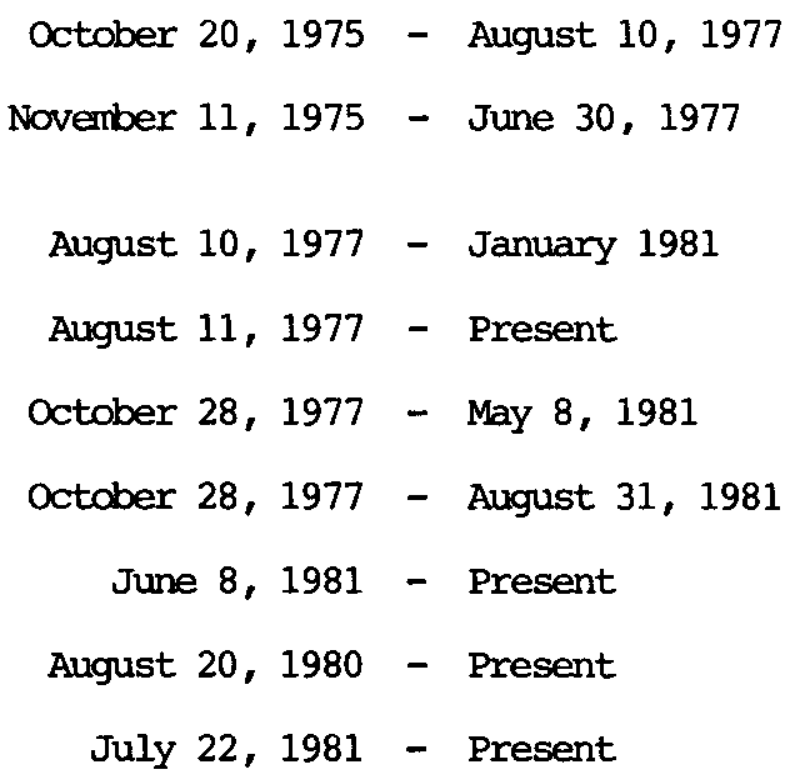

DEPARIMENT OF INTERIOR

\begin{tabular}{r} 
Term of Office \\
\hline $1946-1949$ \\
$1949-1953$ \\
$1953-1956$ \\
$1956-1961$ \\
$1961-1969$
\end{tabular}


DEPARIMENT OF INIERIOR (Cont.)

Walter J. Hickel

$1969-1971$

Rogers C. Morton

$1971-1974$

Stanley K. Hathaway

1975

Thomas S. Kleppe

$1975-1977$

Cecil D. Andrus

$1977-1981$

James Watt

1981 - Present

Assistant Secretaries for Mineral Resources

Felix E. Wormser

Term of Office

Royce A. Hardy

$1954-1957$

$1957-1961$

John M. Kelly

$1961-1965$

John Cordell Moore

$1965-1969$

Hollis M. Dole

$1969-1972$

Assistant Secretary for Energy and Minerals

Stephen A. Wakefield

Term of Office

$1973-1974$

Directors, Office of Oil and Gas

Ralph K. Davies

Term of Office

1946

1947

U.S. DEPARTMENT OF ENERGY/HISTORY DIVISION 
DEPARIMENT OF INIERTOR (Cont.)

Robert E. Friedman, (Acting)

Carroll D. Fentress, (Acting)

Hugh A. Stewart

M. V. Carson, Jr.

Frederick S. Lott, (Acting)

Jerome J. O'Brien

Onnie P. Lattu

Wilson M. Laird

Gene P. Morrell

Duke R. Ligon

Commissioners

William A. Anders, Chairman

Marcus A. Rowden

$$
\text { Chairman }
$$

Edward A. Mason

Victor Gilinsky

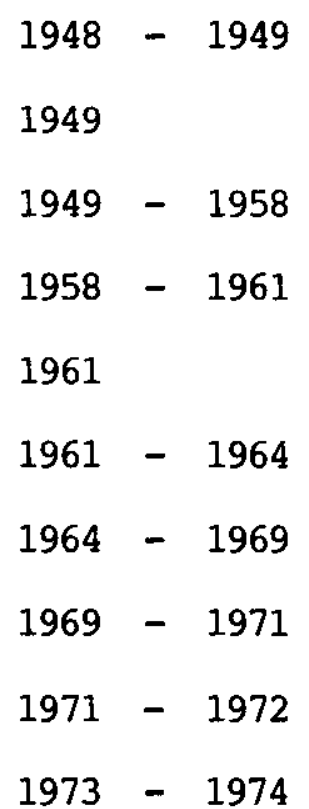

NUCLEAR REGUIATORY COMMISSION

Term of Office

\begin{tabular}{|c|c|}
\hline January 19, 1975 & - April 20, 1976 \\
\hline $\begin{array}{r}\text { January 19, } 1975 \\
\text { April 20, } 1976\end{array}$ & $\begin{array}{l}\text { - June } 30,1977 \\
\text { - June } 30,1977\end{array}$ \\
\hline January 19, 1975 & January 15, 1977 \\
\hline January 19, 1975 & - Present \\
\hline
\end{tabular}


NUCIEAR REGULATORY COMMISSION (Cont.)

Richard T. Kennedy

Joseph M. Hendrie

Chairman

Peter Bradford

John Ahearne

Chaiman

Nunzio Palladino, Chairman

Thamas Roberts

James K. Asselstine
January 19, 1975 - June 30, 1980

August 9, 1977 - June 30, 1981

August 9, 1977 - December 6, 1979

March 3, 1981 - June 30, 1981

August 15, 1977 - March 12, 1982

July 31, 1978 - Present

December 7, 1979 - March 2, 1981

June 24, 1981 - Present

August 3, 1981 - Present

May 31, 1982 - Present 


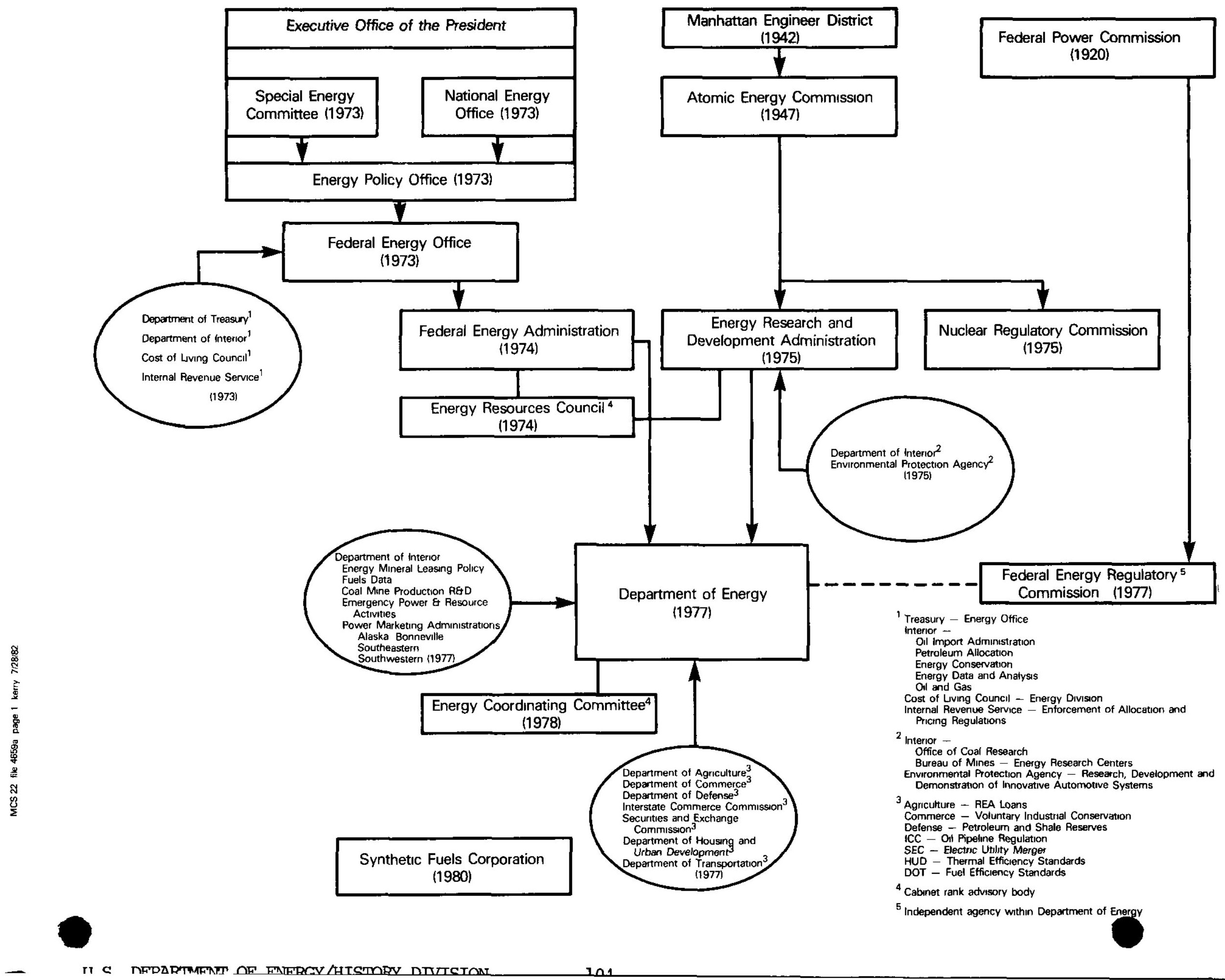

